\title{
Öğretim Elemanlarının Algılarına göre Psikolojik Güçlendirme ile Örgütsel Özdeşleşme Arasındaki İlişskinin İncelenmesi*
}

\section{An Investigation of the Relationship between Psychological Empowerment and Organizational Identification According to the Perceptions of Academic Staff}

\author{
Feyza GÜN**, Tuğba TURABİK***
}

\begin{abstract}
Öz: Bu çalışmanın amacı, öğretim elemanlarının psikolojik güçlendirme ile örgütsel özdeşleşme düzeyleri arasındaki ilişskinin incelenmesidir. İlişkisel tarama modelinin kullanıldığı bu çalışmada, çalışma grubunu Türkiye'deki devlet üniversitelerinde görev yapmakta olan 278 öğretim elemanı oluşturmaktadır. Çalışmada veri toplama aracı olarak "Örgütsel Özdeşleşme Ölçeği” ile "Psikolojik Güçlendirme Ölçeği”" kullanılmıştır. Araştırma sonucunda öğretim elemanlarının psikolojik güçlendirme ile örgütsel özdeşleşme algıları arasındaki ilişskinin orta düzeyde olduğu, öğretim elemanlarının psikolojik güçlendirmeye ilişkin algılarının örgütsel özdeşleşme düzeylerinin anlamlı bir yordayıcısı olduğu ve psikolojik güçlendirme algısının, örgütsel özdeşleşmedeki değişkenliğin \%33’ünü açıkladığı belirlenmiştir.

Anahtar Kelimeler: Psikolojik güçlendirme, örgütsel özdeşleşme, öğretim elemanı, çoklu regresyon
\end{abstract}

\begin{abstract}
The purpose of the present study is to examine the relationship between psychological empowerment and organizational identification according to the perceptions of academic staff. The study, designed as a correlational research, has a total of 278 academic staff working in state universities located in different states in Turkey. As data collection tools, the "Psychological Empowerment Scale" and the "Organizational Identification Scale" were used. The findings revealed that there is a moderate relationship between psychological empowerment perceptions and organizational identification levels of academic staff, and the psychological empowerment perceptions of academic staff are statistically significant predictor of their organizational identification level, and the overall psychological empowerment perceptions of the participants explain $33 \%$ of the variance in organizational identification levels of them. Keywords: Psychological empowerment, organizational identification, academic staff, multiple regression
\end{abstract}

\section{Giriș}

Günümüzde örgütlerin dış çevre koşullarında meydana gelen büyük değişim ve dönüşümlere ayak uydurabilme ihtiyacı, insan unsurunun etkin ve verimli kullanılmasını önemli kılmaktadır. Belli amaçları gerçekleştirmek için kurulan ve bu amaçları gerçekleştirebildiği ölçüde başarıya ulaşabilen örgütlerde, çalıșanlar ile örgüt arasındaki ilișkinin uyumlu olması örgütün gelecekteki durumuna ilişkin sinyaller vermektedir. Bu bağlamda örgüt çalışanının kurumla ilgili olumlu duygular beslemesi ve örgütü benimsemesi önemli görülmektedir. Günümüzde örgütler, çalışanlarından işyerlerinde istikrarlı şekilde uzun süre çalışmaları, bağlılık ve sadakat duygusu ile hareket etmeleri yönünde davranışlar sergilemelerini hatta çalıştıkları örgüt ile bireysel kimliklerini özdeşleştirmelerini beklemektedir (Çakınberk, Derin ve Demirel, 2011). Örgütle özdeşleşen bir çalışan yaptığı işi daha anlamlı hale getirerek ve içselleştirerek motivasyonunu arttırmakta, kendini o örgütün bir parçası gibi hissederek örgüt yararına gönüllü olarak çaba sarf etmektedir (İşcan, 2006). Eğitim örgütlerinin önemli bir yap1 taş1 olan yükseköğretim kurumlarında da öğretim elemanlarının akademik ve öğretimsel becerilerinin uygun olmasının

\footnotetext{
*Bu çalışma, 11-13 Eylül 2014 tarihleri arasında Konya'da düzenlenen 5. Eğitim Yönetimi Forumu'nda sözlü bildiri olarak sunulmuştur.

**Araştırma Görevlisi, Hacettepe Üniversitesi, Eğitim Fakültesi, Ankara-Türkiye, e-posta: feyzagun@ @acettepe.edu.tr ***Araştırma Görevlisi, Hacettepe Üniversitesi, Eğitim Fakültesi, Ankara-Türkiye, e-posta: tugbaturabik@ gmail.com
} 
yanında, çalıştıkları örgütle ilgili olumsuz duygular taşımamaları yerinde olur. Bu durum hem öğretim elemanının etkin ve verimli olarak çalışmasına hem de kurumun bundan azami düzeyde istifade etmesine yardımcı olur. Özdemir (2010) meslekte başarının anahtarlarından birinin de öğretmenlerin okulunu bireysel kimlikleriyle özdeşleştirecek ölçüde benimsemesi ve okulu ile gurur duyması olduğunu belirtmiştir.

Özdeşleşme kavramı Çakınberk ve diğerlerine (2011) göre bireyin örgütle kendini bir olarak algılaması ve örgütün başarı ya da başarısızlığını kendi başarısı ya da başarısızlığı olarak kabul etmesi şeklinde tanımlanırken; örgütsel özdeşleşme, bireyin belirli bir örgüte ait olma algısına sahip olması ve kendini o örgütün bir parçası olarak ifade etmesi şeklinde açıklanmaktadır (Mael ve Ashforth, 1992). Literatür incelendiğinde örgütsel özdeşleşmeyle örgütsel destek, örgütsel prestij, örgütsel bağlılık, örgütsel adalet, liderlik, sinizm, işten ayrılma niyeti, örgütsel güven, örgütsel sosyalleşme, iş doyumu, iş peformansı gibi pek çok farklı kavramın ilişkisinin incelendiği görülmektedir (Balcı, Baltac1, Fidan, Cereci ve Acar, 2012; Çakınberk ve diğerleri, 2011; Çetinkaya ve Çimenci, 2014; İşcan, 2006; Polat ve Meydan, 2010; Sluss, Klimchak ve Holmes, 2008; Tak ve Çiftçioğlu, 2009; Turunç ve Çelik, 2010; Tüzün, 2006; Walumbwa ve diğerleri, 2010; Van Dick, Van Knippenberg, Kerschreiter, Hertel ve Wieseke, 2008). Bu kavramlardan biri de psikolojik güçlendirme olarak karşımıza çıkmaktadır. Spreitzer (1995) psikolojik güçlendirmeyi örgütteki güçlendirme çalışmalarının etkili olabilmesi için çalışanların tecrübe etmesi gereken psikolojik bir durum olarak tanımlanmaktadır (Sürgevil, Tolay ve Topoyan, 2013). Daha açık bir ifadeyle psikolojik güçlendirme, Thomas ve Velthouse'a (1990) göre; "güdüleme, alt kademe çalışanlarının iş yapabilme gücünü arttırma, öz değerlerini ve bağımsızlık duygularını pekiştirme ve kendilerini psikolojik olarak güvende hissetmeleri ile eş anlamlıdır”. Bu tanım düşünülecek olursa psikolojik güçlendirilme algıları yüksek olan bireylerin, örgütsel özdeşleşme algılarında da olumlu yönde bir eğilim olacağı yorumu yapılabilir. Bu varsayımla uyumlu olarak bu çalışmada psikolojik güçlendirme algısının örgütsel özdeşleşme düzeyi üzerindeki etkisi test edilmiştir. Araştırmada test edilen bu varsayım, önceki araştırma bulgularına dayalı olarak temellendirilmiştir. Nitekim bazı araştırmacılar yaptıkları çalışmalarda psikolojik güçlendirmenin, örgütsel özdeşleşmenin belirleyicisi olduğuna ilişkin sonuçlar rapor etmişlerdir (Akın ve Saruhan, 2016; Bulut, 2015; Ertürk, 2010; Polat, Meydan ve Tokmak, 2010; Taştan, 2012; Zhu, Sosik, Riggio ve Yang, 2012). Bu bağlamda çalışmada, yükseköğretim kurumlarında görev yapmakta olan öğretim elemanlarının psikolojik güçlendirme ve örgütsel özdeşleşme düzeyleri arasındaki ilişkiye odaklanılmıştır.

\section{Psikolojik Güçlendirme}

Güçlendirme çeşitli araştırmacılar tarafından farklı şekillerde tanımlanmıştır. Bowen ve Lawler (1992) güçlendirmeyi liderin bilgisini, örgütle ilgili malumatı ve gücünü astlarıyla paylaşması olarak tanımlarken, Erstad (1997) ise çalışanlara işiyle ilgili kararları kendilerinin vermesinin sağlanması ve bu kararın sorumluluğunu alma olanağının verilmesi şeklinde ifade etmiştir. Conger ve Kanungo (1988), güçlendirme kavramını ilişkisel ve motivasyonel bir yapı olarak algılayan iki farklı görüş olduğundan söz etmektedir. Güçlendirmenin ilişkisel bir yapı olduğunu varsayan Burke (1986), Kanter (1983), Likert (1961, 1967) ve McGregor, (1960) gibi baz1 araştırmacılara göre güçlendirme, üstlerin astlarla gücü paylaşmasıdır (aktaran Conger ve Kanungo, 1988). Daha açı bir ifadeyle astlara yetkilerin devredilmesi ve onların kararlara daha çok katılmasının sağlanmasıdır. Bu ifadeler güçlendirme ile yetki devrinin aynı kavramlar olduğu yanılgısına sebebiyet vermektedir. Koçel (2010, s. 410), ikisi arasındaki farkı şu şekilde açıklamaktadır: Güçlendirme çalışanların çeşitli özellikleri itibariyle daha güçlü hale getirilmesi ile ilgilidir oysa yetkilendirme, çalışanı yetkili kılma, ona belli konularda seçim hakkı verme ile ilgilidir. İki kavram arasında esasları bakımından da fark bulunmaktadır zira yetki devrinden kastedilen yöneticinin işin sonucundan sorumlu kişi olarak gerekli gördüğü bazı durumlarda işin daha iyi yapılacağı beklentisiyle yetkisini geçici olarak astına devretmesidir. Güçlendirmenin esası ise işi yapan kişinin uzmanlık bilgisine güvenerek fırsatları görmesini ve gerekli kararları alabilmesini sağlamak yoluyla işe karşı tutumunu değiştirerek kendisini işin sahibi olarak 
görebilmesini sağlamaktır. $\mathrm{Bu}$ açıdan, işini sahiplenen çalışanın o işi daha iyi yapacağı düşünülebilir.

Güçlendirmenin, üstlerin astlarla yetkilerini paylaşması ile aynı şey olduğunu savunan çoğu araştırmacıdan farklı olarak Conger ve Kanungo (1988), güçlendirmenin motivasyonel bir yap1 olduğunu vurgulayarak güçlendirmeyi astlarla yetki paylaşımından çok onlara firsat verme ve onları muktedir kılma olarak ifade etmektedir. Güçlendirmenin motivasyonel bir yap1 olduğunu varsayan diğer araştırmacılardan Bandura (1986), Cameron (1984), Deci (1975) güçlendirmeyi özerklik ve öz-yeterlik ihtiyaçları ile açıklamaktadırlar (aktaran Conger ve Kanungo, 1988). Yazarlara göre özerklik ve öz-yeterlik ihtiyacını güçlendiren yönetimsel stratejiler personelin kendini güçlü hissetmesini ve motivasyonlarının artmasını sağlayacaktır. Bandura (1986), Cameron (1984) ve Deci (1975) ile benzer bir bakış açısına sahip olan Vogt ve Murrel (1990) ise motivasyonel bir yapı olarak güçlendirmeyi "yardımlaşma, paylaşma, yetiştirme ve ekip çalışması yoluyla kişilerin karar verme haklarını (yetkilerini) ve isteklerini artırma ve kişileri geliştirme süreci” olarak tanımlarken, Coffey, Cook ve Hunsaker (1994) "çalışanların kendilerini motive olmuş hissettikleri, bilgi ve uzmanlıklarına olan güvenlerinin arttığ 1 , inisiyatif kullanarak harekete geçme arzusu duyduklar1, olayları kontrol edebileceklerine inandıkları ve organizasyonun amaçları doğrultusunda uygun ve anlamlı buldukları işleri yapmalarını sağlayan uygulama ve koşullar" olarak ifade etmiş̧tir (aktaran Koçel, 2010, s. 409, 411). Conger ve Kanungo'ya (1988) göre ise güçlendirme, güçsüzlüğü artıran durumların saptanması ve bu durumların formal örgüt uygulamaları ve etkili bilgi sağlamada informal tekniklerle ortadan kaldırılmasıyla örgüt üyeleri arasında öz-yeterlik hislerini yükseltme sürecidir.

Güçlendirme kavramının iki esas boyutu vardır. İlk boyut astlarını güçlendiren bir üstün davranışları, ikinci boyut güçlendirilmeye çalışılan astların psikolojik durumudur.Bu iki boyut psikolojik güçlendirmenin temelini oluşturmaktadır (Lee ve Koh, 2001). Psikolojik güçlendirme, üstler tarafından gerçekleştirilen güçlendirme çalışmalarına yönelik astların algılama ve duygularını kapsayan bir durumdur (Ergeneli ve Arı, 2005). Daha basit bir ifadeyle çalışanların kendilerini güçlendirilmiş hissetmeleridir. Güçlendirme gücün paylaşılması ile ilgili bir durumken, paylaşılan gücün çalışanlar tarafından nasıl değerlendirildiği ya da bunu isteyip istemediği güçlendirmenin psikolojik boyutu ile ilgilidir. Conger ve Kanungo'nun (1988) güçlendirme ile ilgili çalışmalarından yola çıkan Thomas ve Velthouse (1990), güçlendirmeyi göreve yönelik içsel bir motivasyon olarak ifade etmişler ve psikolojik güçlendirme kavramının temellerini atmışlardır. Bununla birlikte güçlendirmenin dört boyutu olduğundan söz etmişlerdir: anlamlılık, yeterlilik, seçim ve etki. Spreitzer (1995) yaptığı çalışmada bu boyutları anlamlılık, yeterlilik, özerklik ve etki olarak belirlemiş, boyutların psikolojik güçlendirmeyi açıklayıp açıklamadığına ilişkin geçerlik ve güvenirlik çalışmalarını yapmış ve boyutları doğrulamıştır. Anlamlılık, çalışanların kendi idealleri ve standartları doğrultusunda yaptıkları işin amacına verdikleri değer, bir diğer ifadeyle bireylerin işlerini içten gelen bir şekilde önemsemeleridir (Thomas ve Velthouse, 1990). Anlamlılık, işin gerektirdiği roller ve kişilerin inançları, değerleri ve davranışları arasında bir uyum sağlar (Spreitzer, 1990). Güçlendirilmiş bireyler, yaptıkları işin kendileri için önemli olduğunu düşünerek o işi özenle yaparlar (Quinn ve Spreitzer, 1997). Yeterlilik, Thomas ve Velthouse'a (1990) göre bireyin çabaladığında işi ustalıkla yapabilme derecesidir. Gist'e (1987) göre ise çalışanların bir işi gerçekleştirmede yeteneklerine ve kapasitesine olan inancıdır. Yüksek yeterlilik inancı engeller karşısında daha fazla gayret sarf etmeyi ve dayanıklılığı sağlar. Düşük yeterlilik inancı ise bireyleri yetenek gerektiren işlerden kaçınmaya iter. Özerklik, bireyin eylemlerini başlatmada ve düzenlemede karar sahibi olma hissidir (Deci, Connel ve Ryan, 1989). Özerklik işe başlanmasında ve devam edilmesinde çalışanların sahip olduğu otonomiyi ifade etmektedir. Etki, Ashfort (1989)'a göre bir çalışanın örgütteki stratejik, yönetimsel veya işletme ile ilgili çıtıllar üzerinde etkili olma derecesidir (aktaran Spreitzer, 1995). Çalışanların işyerlerinde bir iz bırakabilme ve örgütün onların fikirlerini ciddiye alma düzeyini gösterir (Sürgevil ve diğerleri, 2013). Etki, örgütsel katılımı ifade etmektedir ve çalışanların örgütte değişim gerçekleştirip gerçekleştiremediklerine dair hislerini yansıtmaktadır (Spreitzer, Kizilos ve Nason, 1997). Psikolojik güçlendirmeyi oluşturan bu dört boyut sağlandığında çalışanlar, yaptıkları iş ve iş çevresi üzerinde daha fazla kontrol sahibi 
olduklarını hissederler (Menon ve Hartmann, 2002; Spreitzer, 1995). Bu durumun çalışanların verimini, dolayısıyla örgütün etkililiğini artıracağını düşünmek mümkündür. Bununla birlikte literatürde psikolojik güçlendirmenin örgütsel bağlllık, örgütsel adalet, örgütsel özdeşleşme, iş tatminini arttırdığına ve personel örgütsel sinizmi ile iş güvensizliğini azalttığına yönelik çeşitli çalışmalar yer almaktadır (Arslantaş, 2008; Avey, Hughes, Norman ve Luthans, 2008; Carless, 2004; Ertürk, 2010; Lee ve Nie, 2014; Polat ve diğerleri, 2010; Prati ve Zani, 2013; Somuncuoğlu, 2013; Stander ve Rothmann, 2010; Vacharakiat, 2008; Yürür ve Demir, 2011). Psikolojik güçlendirmenin örgüt için istenen durumlar ile olan olumlu ilişkilerine yönelik ulaşılan bu sonuçlar konunun örgütler açısından önemini ortaya koymaktadır.

\section{Örgütsel Özdeşleșme}

Alanyazında ilk olarak Lasswell (1935) tarafindan, psikoloji, sosyoloji ve söz bilimle ilgili bir kavram olarak kullanılan özdeşleşme, birey ve diğer insanlar arasındaki duygusal ilişkinin sonucunda ortaya çıkan benzerlik algısının oluşma süreci olarak tanımlanmıştır (aktaran Tokgöz ve Aytemiz Seymen, 2013). Scott, Corman ve Cheeney (1998) özdeşleşmeyi yapısal bir bakış açısıyla, kimliği meydana getiren ve aynı zamanda kimliğin oluşturduğu bir davranış türü olarak nitelendirmiştir. Bir bireyin başka bir birey veya gruptan kaynaklanan davranışları benimsemesi sonucu oluşan özdeşleşme, kişilerin kendi çevrelerini oluşturmak veya özsaygılarını artırmak gibi nedenlerden dolayı tercih ettikleri bir süreçtir (Stoner ve Gallagher, 2011). Bireyin benimsediği bu davranışlar onun grupla veya bireyle olan bağlarının daha çok güçlenmesine neden olmaktadır.

Örgütsel özdeşleşme ise sosyal kimlik kuramının bir bileşeni olarak karşımıza çıkmaktadır (Ashforth ve Mael, 1989), Yazarlar sosyal kimliği "kişinin bilgisinden ya da sosyal bir gruba ya da gruplara üyeliğinden ve bu üyeliğe duygusal ve değersel olarak bağl1lığından türeyen kişinin sosyal bağlamının bir parçası" olarak tanımlamıştır. Sosyal kimlik kuramını ortaya koyan Tajfel (1972) ise bireyin, belirli bir grubun üyeliğine duygusal ve değersel bir önem verme suretiyle bu gruba ait olma bilgisi olarak ifade etmiştir (aktaran Bartels, 2006). Sosyal kimlik kuramına göre kişiler kendilerini cinsiyet, meslek, örgüt üyeliği, politik görüş gibi çeşitli sosyal kategorilere ait görürler. Bu kategorilerin taşıdığı özellikler kişilerin kendilerini tanımlamasına imkân sağlamakta, onların kendileri ile ilgili görüşlerini etkilemektedir. Sosyal kimlik kuramı temel alındığında örgütsel amaç ve hedeflerin gerçekleştirilmesi için çalışanların destekleyici davranışlar sergilemelerinin üzerinde örgütsel özdeşleşmenin olumlu yönde katkısı vardır (Hekman, Steensma, Bigley ve Hereford, 2009). Birey ve örgüt arasındaki ilişkiye odaklanan örgütsel özdeşleşme (Tompkins ve Cheney, 1985, s. 45), kişinin psikolojik yönden, çalıştığ örgütü kendisinin bir parçasıymış gibi hissetmesi (Scott ve Lane, 2000) olarak ifade edilmiştir. Kişinin çalıştığ 1 örgütle kurduğu bu psikolojik bağ, örgütün tanımlayıc1 özelliklerini kendi özellikleriymiş gibi benimsediğinde kurulmuș olur (Reade, 2001, s.1270).

Örgütsel bağlamda özdeşleşmenin ilk kez kullanılması Foote (1951) tarafindan yapılmış, özdeşleşmeyi motivasyon için bir temel olarak ele almıştır. Yazara göre belirli bir kimliğe veya kimlikler dizisini sahiplenen ve ona bağlanan kişiler, kendi eylemlerini düzenleyerek bu yolla etraflarındaki sosyal dünyayı kategorize ederler. Brown (1969) örgütsel özdeşleşmeyi kendini tanımlamaya yanıt olarak, örgüt ile birey arasında özel bir ilişkinin kurulması olarak formüle etmiştir. Örgütsel özdeşleşmenin gerçekleşebilmesi için bireyin örgütten hoşlanması, örgütsel ve bireysel hedeflerin tutarlılı̆̆1, örgüte sadakat, kendi benliğine örgüt üyeliğini referans gösterme olmak üzere dört yönlü bir etkiye işaret etmiştir. Lee (1971) örgütsel özdeşleşmeyi kişilerin örgüt ile bireysel özdeşleşmesinin derecesi olarak tanımlamış, özdeşleşmenin ait olma hissi, sadakat veya paylaşılan özellikler olmak üzere üç ayrı bileşenden meydana gelebileceğini öne sürmüştür. Cheney ve Tompkins (1987) örgütsel özdeşleşmeye farklı bir bakış açısı getirerek bu olguya süreç ve çıktı perspektifinden bakmış, örgütsel özdeşleşmenin kimlik oluşturma sürecinin bir sonucu olduğunu vurgulamıştır. Bu süreçte kullanılan dil, başka bir deyişle örgüt içerisindeki iletişim bu sürecin şekillenmesinde etkilidir. Walsh ve Gordon (2008) ise örgütsel özdeşleşmeyi, bireylerin kendilerini bir örgüt üyeliği ile tanımlama derecesi olarak tanımlamıştır. Özdeşleşme kendisini bir örgütün üyesi olarak görmekten ziyade, bireyin benlik kavramında örgütün ne kadar yer tuttuğu ile ilgilidir (Ashforth, Harrison ve Corley, 2008). İşgörenler çalıştıkları örgüte karş1 
aidiyet duygusu hissettiklerinde örgütün özelliklerini kendi kişisel özellikleriymiş gibi tanımlama eğilimi gösterirler (Dutton, Dukerich ve Harquail, 1994).

Örgütsel özdeşleşme, hem bireyin tatminini hem de örgütlerin verimini etkilemektedir (Ashforth ve Mael, 1989). Özdeşleşmiş çalışanlar örgütle dayanışma duygusu içinde olarak, örgüte destek olmakta (Riketta, 2005), örgütün amaçlarını kendi amaçları haline getirerek zor işlere karşı daha fazla motive olabilmektedirler (Edwards, 2005). Çalıştıkları örgüt ile kendilerini özleştiren çalışanlar, örgütte karşılaştıkları sorunları kendi sorunlarıymış gibi benimseyerek çözüm geliştirmeye çalışılacak ve örgütlerinin ilerlemesi için daha fazla çaba göstereceklerdir. Çalışanlar örgütleriyle ne kadar fazla özdeşleşirse, örgüt yararına o kadar fazla çalışacaklardır (Christ ve diğerleri, 2003). Çünkü bireyler örgüt çıkarlarını kendi çıkarları gibi benimseyeceğinden, örgütsel değerlere ve amaçlara güçlü bir şekilde inanacaklar ve onları gerçekleştirmek için işlerini isteyerek yapacaklardır. Kendilerini örgütün bir temsilcisi olarak gören çalışanlar, alacakları bütün kararlarda ve atacakları tüm adımlarda örgüt menfaatini ön planda tutacaklardır. Paralel şekilde özdeşleşme algıları yüksek olan çalışanların iş doyumları artmakta, daha fazla ekstra rol davranışı sergilemekte, işten ayrılma niyetleri azalmakta, işe daha az devamsızlık yapmaktadırlar (Bartels, 2006). Başka bir deyişle çalışanlar kendilerini bir grubun parçası olarak gördükçe, içinde bulundukları grup da onların davranışlarını o yönde etkilemektedir (Gabler, Rapp ve Richey, 2014). Çalışanların örgütle bir olma algıları arttıkça örgüt içi işbirliği ve örgütsel vatandaşlık gibi istenen örgütsel çıktılar sağlanabilmektedir (Dutton ve diğerleri, 1994).

Örgütsel özdeşleşmenin artmasını sağlayan faktörlerden birinin psikolojik güçlendirme olabileceği düşünülmektedir. Alanyazında psikolojik güçlendirmenin örgütsel özdeşleşme üzerindeki etkisinin incelendiği ve iki değişken arasında pozitif yönlü anlamlı ilişkilerin bulunduğu çalışmalar mevcuttur (Ertürk, 2010; Meydan, Polat ve Burmaoğlu, 2010; Polat ve diğerleri, 2010; Prati ve Zani, 2013; Yarmac1, 2012; Zhu ve diğerleri, 2012). Ancak öğretim elemanlarının psikolojik güçlendirme ve örgütsel özdeşleşme düzeyleri arasındaki ilişkiyi inceleyen çalışmalara rastlanamamıştır. Dolayısıyla öğretim elemanlarının performansı üzerinde etki gösterebileceği öngörülen bu iki değişkenin incelenmesinin ve keşfedilmesinin, eğitim süreçlerinin geliştirilmesine ayrı bir katkı getirebileceği düşünülmüştür. Buradan hareketle de bu araştırmada, psikolojik güçlendirme ile örgütsel özdeşleşme arasındaki ilişkinin öğretim elemanlarının algılarına göre incelenmesi amaçlanmıştır. Bu kapsamda, araştırmada şu sorulara yanıt aranmiştır:

1. Öğretim elemanlarının psikolojik güçlendirme ve örgütsel özdeşleşme algıları ne düzeydedir?

2. Öğretim elemanlarının psikolojik güçlendirme ve örgütsel özdeşleşme düzeyleri arasında anlamlı bir ilişki var mıdır?

3. Öğretim elemanlarının psikolojik güçlendirme ve örgütsel özdeşleşme düzeyleri katılımcıların cinsiyet, kadro unvanı, hizmet süresi değişkenlerine göre farklılaşmakta midır?

4. Öğretim elemanlarının psikolojik güçlendirme algıları, örgütsel özdeşleşme düzeylerinin anlamlı bir yordayıcisı midir?

\section{Yöntem}

Psikolojik güçlendirme ile örgütsel özdeşleşme arasındaki ilişkinin öğretim elemanlarının algılarına göre incelenmesini konu alan bu araştırma ilişkisel tarama modelinde desenlenmiştir. Bu kapsamda elde edilen veriler nicel teknikler kullanılarak analiz edilmiştir. Bu araştırma iki ya da daha fazla değişken arasında birlikte değişim varlığını ve değişim varsa bunun derecesini belirlemeyi amaçladığı, ayrıca var olan durumu olduğu gibi yansıtmaya çalıştığı için ilişkisel tarama modeli ile desenlenmiştir (Karasar, 2014, s. 81).

\section{Çalıșma Grubu}

Araştırmanın çalışma grubunu Türkiye' deki çeşitli devlet üniversitelerinde görev yapmakta olan 278 öğretim elemanı oluşturmaktadır. Veriler 2013-2014 öğretim yılı bahar döneminde 
toplanmıştır. Araştırmaya katılan öğretim elemanlarının 119'u kadın, 159'u erkektir. Katılımcıların 50'si 22-27 yaş, 99'u 28-33 yaş, 53'ü 34-39 yaş, 34'ü 40-45 yaş, 42'si 46 ve üzeri yaş grubu aralığındadır. Katılımcıların 188'i 1-10 yıl, 53'ü 11-20 yıl, 37'si 21 yıl ve üzeri hizmet süresine sahiptir. Katılımcıların 30'u profesör, 31'i doçent, 65'i yardımcı doçent, 119'u araştırma görevlisi, 33’ü ise ögretim görevlisi, okutman ve uzmanlardan oluşmaktadır.

\section{Veri Toplama Araçları}

Araştırmada öğretim elemanlarının örgütsel özdeşleşmeye yönelik algılarını ölçmek amacıyla Mael ve Ashforth (1992) tarafından geliştirilmiş olan ve Türkçe'ye uyarlaması Tüzün (2006) tarafından yapılan "Örgütsel Özdeşleşme Ölçeği (ÖÖÖ)" kullanılmıştır. ÖÖÖ, "kesinlikle katılmıyorum" ile "kesinlikle katılıyorum" arasında değer alan 5 dereceli Likert tipi bir ölçektir. 7 maddeden oluşan ölçek, tek faktörden oluşmaktadır. Ölçeği Türkçe’ye uyarlayan Tüzün (2006) Cronbach alpha iç tutarlılık katsayısını .78 olarak bulmuştur. Bu araştırma kapsamında, araştırmanın çalışma grubu üzerinde yapılan güvenirlik analizi sonucunda ölçeğin tümüne ait Cronbach alfa katsayısı .87 olarak tekrar hesaplanmış olup, ölçeğin bu araştırma için güvenilir olduğuna karar verilmiştir. Ölçeğin geçerlik çalışmaları kapsamında doğrulayıcı faktör analizi (DFA) yapılmış, elde edilen uyum iyiliği sonuçları şu şekilde bulunmuştur: $\left[\mathrm{X}^{2}=35,05\right.$; $\mathrm{sd}=14$; $\mathrm{X}^{2} / \mathrm{sd}=2,50 ; \mathrm{AGFI}=, 93 ; \mathrm{GFI}=, 97 ; \mathrm{NFI}=, 98 ; \mathrm{CFI}=, 98 ; \mathrm{IFI}=, 98 ; \mathrm{RMR}=, 036$ ve RMSEA =,074]. ÖÖÖ'nün tek faktörlü yapısına ilişkin oluşturulan modelin uygunluğu, öncelikle hesaplanan uyum indekslerinden ki-kare değerinin serbestlik derecesine oranıyla değerlendirilmiştir. Kline (2005)'a göre ki-kare değerinin serbestlik derecesine oranının 5'ten küçük olması gerekmektedir. Byrne ve Campbell (1999) ise uyum iyiliği indekslerinde AGFI, GFI, NFI, CFI, IFI için kabul edilebilir uyum değerlerinin .90 ve üzeri olduğu, RMR ve RMSEA için ise 0.08 ve daha aşağısı olduğunu belirtmiştir. Buna göre ÖÖÖ'nün, yapılan analizler sonucunda bu çalışmada kullanılabilecek geçerli bir araç olduğu söylenebilir.

Öğretim elemanlarının psikolojik güçlendirmeye yönelik algılarını ölçmek için ise Spreitzer (1995) tarafindan geliştirilmiş olan ve Türkçe'ye uyarlaması Sürgevil ve diğerleri (2013) tarafindan yapılan "Psikolojik Güçlendirme Ölçeği (PGÖ)" kullanılmıştır. PGÖ, "kesinlikle katılmiyorum" ile "kesinlikle katılıyorum" arasında değer alan 5 dereceli Likert tipi bir ölçektir. 12 maddeden oluşan ölçek, 4 faktörden (anlamlılık, yeterlilik, özerklik, etki) oluşmaktadır. Ölçeği Türkçe’ye uyarlayan Sürgevil ve diğerleri (2013) Cronbach alpha iç tutarlılık katsayısını etki, yeterlilik, anlamlılık, özerklik boyutları için sırasıyla $.89, .85, .84$ ve .85 olarak hesaplamıştır. Bu araştırma kapsamında güvenirlik analizi tekrar yapılmış olup, ölçeğin tümüne ait Cronbach alfa katsayısı .90 , etki, yeterlilik, anlamlılık ve özerklik boyutları içinise Cronbach alfa katsayıları sırasıyla $.96, .84, .88$ ve .89 olarak hesaplanmıştır. Elde edilen bulgular ölçeğin bu araştırma için güvenilir bir ölçme aracı olduğunu göstermiştir. Ölçeğin geçerlik çalışmaları ise doğrulayıcı faktör analizi (DFA) ile yapılmış, elde edilen uyum iyiliği sonuçları şu şekilde bulunmuştur: [ $\mathrm{X}^{2}=147,38$; sd $=48 ; \mathrm{X}^{2}$ /sd =3,07; AGFI =,87; GFI =,92; NFI =,96; CFI $=, 98 ; \mathrm{IFI}=, 98 ; \mathrm{RMR}=, 058$ ve RMSEA =,086]. PGÖ' nün dört faktör yapısına ilişkin elde edilen uyum iyiliği indeksleri kabul edilebilir sınırlarda çıkmıştır (Byrne ve Campbell, 1999; Kline, 2005). Dolayısıyla PGÖ’ nün bu çalışmada da kullanılmaya elverişli ve geçerli bir araç olduğuna karar verilmiştir.

\section{Verilerin Çözümlenmesi}

Veri seti ön incelemeye tabi tutulmuş ve ölçeklere ilişkin veri setinin normal dağılım gösterdiğini belirlemek amacıyla kullanılan her bir ölçek için basıklık ve çarpıklık değerleri hesaplanmış, değerlerin -1 ve +1 arasında değiştiği gözlenmiştir. Puan dağılımlarının çarpıklık ve basıklık değerinin -1 ile +1 arasında olması nedeniyle normal dağıldığ 1 varsayılmıştır (George ve Mallery, 2001; Leech, Barrett ve Morgan, 2011). Elde edilen verilerin normal dağılıma uygunluk gösterip göstermediğinin belirlenmesi için Kolmogorov-Smirnov (K-S) testinden de faydalanılmıştır. Gerçekleştirilen Kolmogorov-Smirnov Testi sonucunda Psikolojik Güçlendirme Ölçeği'nin tüm alt boyutları $\left(\mathrm{K}-\mathrm{S}_{\text {Etki }}=0,126, \mathrm{~K}-\mathrm{S}_{\text {Yeterlilik }}=0,181, \mathrm{~K}-\mathrm{S}_{\text {Anlamlllik }}=0,223, \mathrm{~K}-\mathrm{S}_{\text {Özrklik }}=0,143\right)$ ve Örgütsel Özdeşleşme Ölçeği $\left(\mathrm{K}-\mathrm{S}_{\text {özdeşlessme }}=0,095\right)$ için bulunan $p$ değerinin 0,05 'den büyük olduğu ve 
normallik dağılımı varsayımının sağlandığı görülmüştür. Bu bulgu veri setinin parametrik analize uygun olduğunu göstermiştir. Araştırma kapsamında kullanılan ölçeklerin güvenirliğinin belirlenmesi için Cronbach alfa iç tutarlılık katsayıları tekrar hesaplanmıştır. Veri toplama araçlarının yapı geçerliği ise doğrulayıcı faktör analizi ile sınanmıştır.

Araştırma kapsamında elde edilen veriler aritmetik ortalama, standart sapma, frekans, yüzdelik, $t$ testi, tek yönlü varyans analizi (ANOVA), pearson korelasyon katsayısı ve regresyon analizi ile incelenmiştir. Anlamlı çıkan $F$ değeri için, farkın kaynağını belirlemek üzere LSD testi kullanılmıştır. Anlamlılık düzeyi $p<.05, p<.01$ ile $p<.001$ olarak alınmıştır. Genel ağırlıklı aritmetik ortalamalar yorumlanırken aralıklar 1.00-1.79 oldukça düşük; 1.80-2.59 düşük; 2.60 3.39 orta; 3.40-4.19 yüksek; 4.20-5.00 aralığ 1 ise oldukça yüksek olarak değerlendirilmiştir. Bu aralıklar, ölçek maddelerine verilen en düşük " 1 " ile en yüksek "5" puanlarının arasındaki seri genişliğinin seçenek sayısına bölünmesi ile elde edilmiştir.

\section{Bulgular}

Öğretim elemanlarının örgütsel özdeşleşmeye ve psikolojik güçlendirmeye yönelik algılarına ilişkin ortalama ve standart sapma puanları ile bu iki değişken arasındaki ilişkiyi belirlemek için yapılan Pearson Korelasyon katsayısı hesapları Tablo 1'de verilmiştir.

Tablo 1

Örgütsel Özdeşleşme ile Psikolojik Güçlendirme Arasındaki İlişkiye İlişkin Pearson Korelasyon Katsayı Değerleri ile Ölçeklere Ait Ortalama ve Standart Sapma Puanları

\begin{tabular}{|c|c|c|c|c|c|c|c|c|}
\hline Ölçek & Ort. & Ss. & 1 & 2 & 3 & 4 & 5 & 6 \\
\hline 1 Örg. Özdeș. & 3,13 &, 86 & 1 & & & & & \\
\hline 2 Psi. Güçl. & 3,75 & ,69 &, $52^{* *}$ & 1 & & & & \\
\hline 3 Anlamlilik & 4,32 &, 78 &, $35^{* *}$ &, $75^{* *}$ & 1 & & & \\
\hline 4 Yeterlilik & 4,35 &, 65 &, $18^{* *}$ &, $66^{* *}$ &, $61^{* *}$ & 1 & & \\
\hline 5 Özerklik & 3,60 & 1,02 &, $53^{* *}$ &, $84^{* *}$ &, $50^{* *}$ &, $40^{* *}$ & 1 & \\
\hline 6 Etki & 2,71 & 1,15 &, $44^{* *}$ &, $79^{* *}$ &, $35^{* *}$ &, $26^{* *}$ &, $58^{* *}$ & 1 \\
\hline
\end{tabular}

Tablo 1'den de görüldüğü gibi öğretim elemanlarının örgütsel özdeşleşmeye ilişkin alg1 düzeylerinin ortalaması 3,13 'tür. Öğretim elemanlarının psikolojik güçlendirmeye ilişkin alg1 düzeylerinin ortalaması ise $3,75^{\prime}$ tir. Buna göre öğretim elemanlarının örgütsel özdeşleşmeye ilişkin algıları orta düzeyde iken psikolojik güçlendirmeye ilişkin algıları yüksek düzeydedir. Ortalamalar psikolojik güçlendirmenin alt boyutları bazında incelendiğinde ise öğretim elemanlarının yeterlilik boyutuna ilişkin algılarının en yüksek düzeyde olduğu görülmektedir. Örgütsel özdeşleşme ile psikolojik güçlendirme arasında ise anlamlı ve orta düzeyde bir ilişki olduğu belirlenmiştir $(\mathrm{r}=.52 ; p<.01)$. Aynı şekilde örgütsel özdeşleşmenin, psikolojik güçlendirmenin yeterlilik hariç her alt boyutu için orta düzeyde anlamlı ilişkiler gösterdiği görülmektedir $\left[\left(\mathrm{r}_{\text {anlamlll1k x öÖ }}=.35 ; p<.01\right) ;\left(\mathrm{r}_{\text {yeterlilik x ÖÖ }}=.18 ; p<.01\right) ;\left(\mathrm{r}_{\text {özerklik x ÖÖ }}=.53 ; p<.01\right)\right.$; $\left.\left(\mathrm{r}_{\text {etki x öö }}=.44 ; p<.01\right)\right]$. Bu bulgulardan da anlaşılacağı gibi öğretim elemanlarının örgütsel özdeşleşme algıları en yüksek, özerklik boyutu ile ilişkili çıkmıştır.

Katılımcıların cinsiyetlerine göre öğretim elemanlarının örgütsel özdeşleşme ve psikolojik güçlendirmeye ilişkin algı düzeylerinin anlamlı bir farklılık gösterip göstermediğini saptamak amaciyla $t$-testi uygulanmıştır. Tablo 2 'te cinsiyet değişkenine göre $t$-testi sonuçları verilmiştir.

Tablo 2

Öğretim Elemanlarının Örgütsel Özdeşleşmeye ve Psikolojik Güçlendirmeye İlişkin Algı Düzeylerinin Cinsiyet Değişkenine Göre t-testi Sonuçları

\begin{tabular}{llcccccc}
\hline Ölçek & Cinsiyet & $\mathrm{N}$ & Ort. & Ss. & Sd. & $t$ & $p$ \\
\hline Örgütsel & Kadın & 119 & 3,18 &, 77 & 276 &, 751 &, 453 \\
Özdeşleşme & Erkek & 159 & 3,10 &, 93 & & &
\end{tabular}


Öğretim Elemanlarının Algılarına göre Psikolojik Güçlendirme ile Örgütsel Özdeşleşme Arasındaki İlişkinin İncelenmesi

\begin{tabular}{llllllll} 
Psikolojik. & Kadın & 119 & 3,56 &, 70 & 276 & $-4,052$ &, $000^{* * *}$ \\
$\begin{array}{l}\text { Güçlendirme- } \\
\text { Toplam }\end{array}$ & Erkek & 159 & 3,89 &, 67 & & & \\
Anlamlılık & Kadın & 119 & 4,19 &, 80 & 276 & $-2,386$ &, $018^{*}$ \\
& Erkek & 159 & 4,42 &, 76 & & & \\
Yeterlilik & Kadın & 119 & 4,26 &, 67 & 276 & $-1,901$ &, 058 \\
& Erkek & 159 & 4,41 &, 63 & & & \\
Özerklik & Kadın & 119 & 3,38 & 1,04 & 276 & $-3,265$ &, $001^{* *}$ \\
\multirow{2}{*}{ Etki } & Erkek & 159 & 3,77 &, 97 & & & \\
& Kadın & 119 & 2,38 & 1,11 & 276 & $-4,132$ &, $000^{* *}$ \\
\hline & Erkek & 159 & 2,95 & 1,12 & & & \\
\hline
\end{tabular}

Tablo 2'den de görüldüğü üzere öğretim elemanlarının örgütsel özdeşleşmeye ilişkin algıları cinsiyet değişkenine göre istatistiksel olarak anlamlı bir fark göstermemektedir $\left(t_{(276)}=\right.$ ,751, $p>.05)$. Bu bulgu kadın ve erkek öğretim elemanlarının örgütsel özdeşleşmeye yönelik algılarının benzer düzeyde olduğuna işaret etmektedir. Ancak öğretim elemanlarının psikolojik güçlendirmeye ilişkin algıları cinsiyet değişkenine göre erkeklerin lehine istatistiksel olarak anlamlı bir fark göstermektedir $\left(t_{(276)}=-4,052, p<.001\right)$. Psikolojik güçlendirmenin alt boyutlarının katılımcıların cinsiyetlerine göre anlamlı bir farklılık gösterip göstermediği incelendiğinde ise anlamll1ık $\left(t_{(276)}=-2,386, p<.05\right)$, özerklik $\left(t_{(276)}=-3,265, p<.001\right)$ ve etki $\left(t_{(276)}=-4,132, p<.001\right)$ boyutlarında erkeklerin lehine anlamlı bir fark bulunduğu gözlenmektedir.

Katılımcıların kadro unvanına göre öğretim elemanlarının örgütsel özdeşleşmeye ve psikolojik güçlendirmeye ilişkin algı düzeylerinin anlamlı bir farklılık gösterip göstermediğini saptamak amacıyla ANOVA uygulanmıştır. Tablo 3'te unvan değişkenine göre ANOVA sonuçları ile farkın kaynağını belirlemek üzere yapılan LSD testi sonuçları verilmiştir.

Tablo 3

Öğretim Elemanlarının Örgütsel Özdeşleşmeye ve Psikolojik Güçlendirmeye İlişkin Algı Düzeylerinin Unvan Değişkenine Göre ANOVA Sonuçları

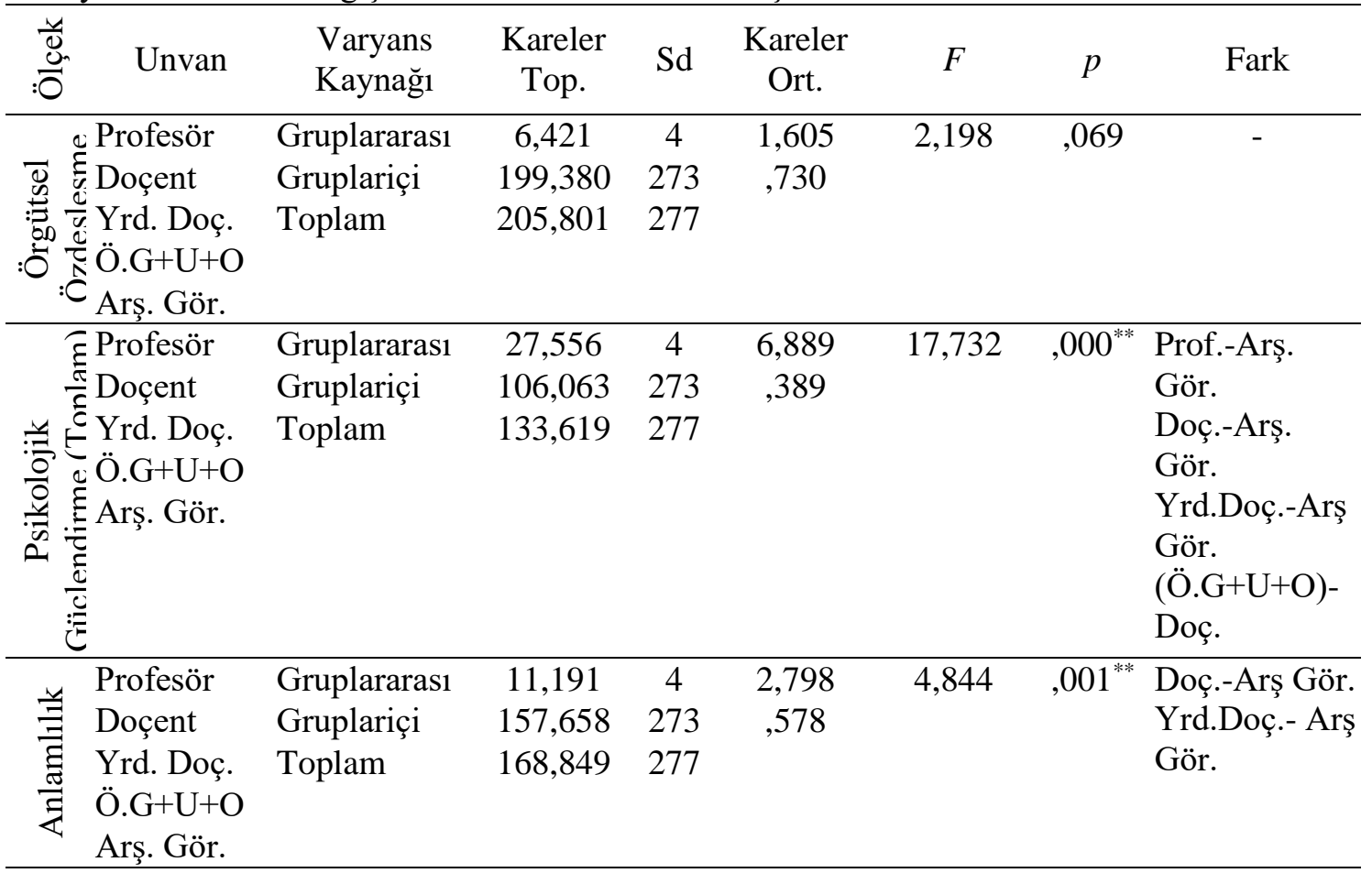




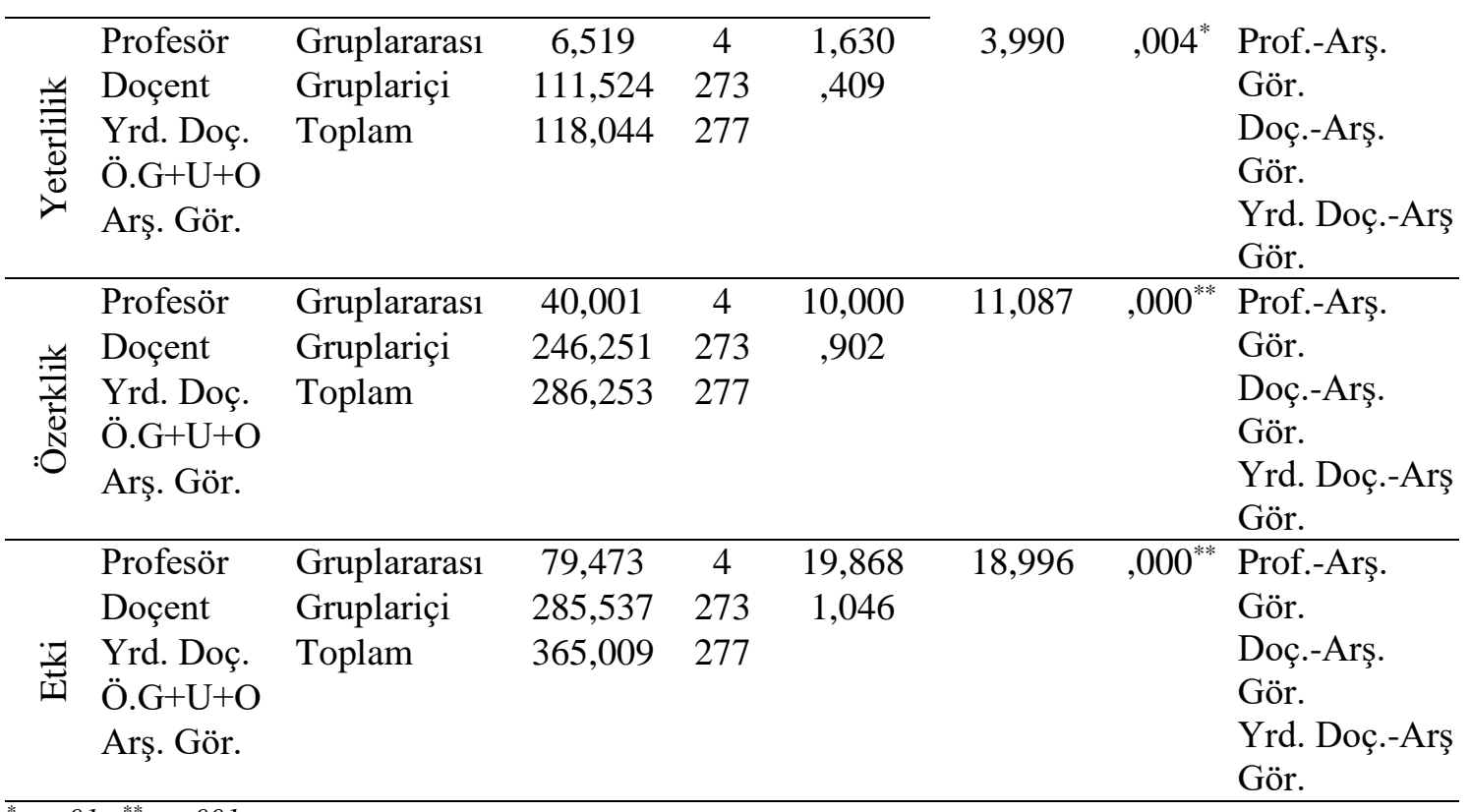

${ }^{*} p<.01 \quad{ }^{* *} p<.001$

Tablo 3'ten de izlenebileceği gibi öğretim elemanlarının örgütsel özdeşleşmeye ilişkin alg1 düzeylerinde unvan değișkenine göre istatistiksel olarak anlamlı bir fark gözlenmemișken $\left(F_{(4-273)}=2,198, p>.05\right)$, psikolojik güçlendirmeyi algılama düzeylerinde unvan değişkenine göre istatistiksel olarak anlamlı bir fark bulunmuştur $\left(F_{(4-273)}=17,732, p<.001\right)$. Farkın kaynağını saptamak üzere yapılan LSD testi sonuçlarına göre araştırma görevlileriyle $(\bar{X}=3,46)$; profesörler $(\bar{X}=4,23)$, doçentler $(\bar{X}=4,20)$ ve yardımcı doçentler $(\bar{X}=4,04)$ arasında; öğretim görevlisi+uzman+okutmanlar ile $(\bar{X}=3,67)$ doçentler $(\bar{X}=4,20)$ arasında; istatistiksel olarak anlamlı bir fark olduğu saptanmıştır. Bununla birlikte katılımcıların unvan değişkenine göre psikolojik güçlendirmenin tüm alt boyutlarında da anlamlı bir farklılık tespit edilmiştir. Anlamlılık boyutunda araştırma görevlilerinin $(\bar{X}=4,15)$, doçent $(\bar{X}=4,62)$ ve yardımc1 doçentlerle $(\bar{X}=4,52)$; yeterlilik boyutunda araştırma görevlilerinin $(\bar{X}=4,21)$, profesör $(\bar{X}=4,67)$, doçent $(\bar{X}=4,58)$ ve yardımcı doçentlerle $(\bar{X}=4,45)$; özerklik boyutunda araştırma görevlilerinin $(\bar{X}=3,26)$, profesör $(\bar{X}=4,18)$, doçent $(\bar{X}=4,09)$ ve yardımcı doçentlerle $(\bar{X}=4,01)$; etki boyutunda ise yine araştırma görevlilerinin $(\bar{X}=2,20)$, profesör $(\bar{X}=3,45)$, doçent $(\bar{X}=3,51)$ ve yardımcı doçentlerle $(\bar{X}=3,20)$ arasında anlamlı bir fark gözlenmiștir. Buna göre, araștırma görevlilerinin psikolojik güçlendirmeyi algılama düzeylerinin diğer meslektaşlarından görece daha düşük olduğu belirlenmiştir.

Katılımcıların hizmet süresine göre öğretim elemanlarının örgütsel özdeşleşmeye ve psikolojik güçlendirmeye ilişkin algı düzeylerinin anlamlı bir farklılık gösterip göstermediğini saptamak amacıyla ANOVA uygulanmıştır. Tablo 4'te hizmet yılı süresi değişkenine göre ANOVA sonuçları ile farkın kaynağını belirlemek üzere yapılan LSD testi sonuçları verilmiştir.

Tablo 4

Öğretim Elemanlarının Örgütsel Özdeşleşmeye ve Psikolojik Güçlendirmeye İlişkin Alg1 Düzeylerinin Hizmet Süresi Değişkenine Göre ANOVA Sonuçları

\begin{tabular}{|c|c|c|c|c|c|c|c|c|}
\hline $\begin{array}{l}\frac{y}{0} \\
: \frac{0}{0}\end{array}$ & $\begin{array}{l}\text { Hizmet } \\
\text { Süresi }\end{array}$ & $\begin{array}{l}\text { Varyans } \\
\text { Kaynağ1 }\end{array}$ & $\begin{array}{c}\text { Kareler } \\
\text { Top. }\end{array}$ & $\mathrm{Sd}$ & $\begin{array}{l}\text { Kareler } \\
\text { Ort. }\end{array}$ & $F$ & $p$ & $\begin{array}{c}\text { Farkın } \\
\text { Kaynağı }\end{array}$ \\
\hline \multirow{3}{*}{$\begin{array}{l}: 0 \\
: 0\end{array}$} & 10 y1l ve alt1 & Gruplararas1 & 1,972 & 2 & ,986 & 1,330 & ,266 & - \\
\hline & 11-20 y1l & Gruplariçi & 203,830 & 275 & ,741 & & & \\
\hline & $21 \mathrm{y} 1 \mathrm{l}$ ve üst & Toplam & 205,801 & 277 & & & & \\
\hline & 10 y1l ve alt1 & Gruplararas1 & 7,041 & 2 & 3,520 & 7,648 & $001^{* * *}$ & \\
\hline
\end{tabular}


Öğretim Elemanlarının Algılarına göre Psikolojik Güçlendirme ile Örgütsel Özdeşleşme Arasındaki İlişkinin İncelenmesi

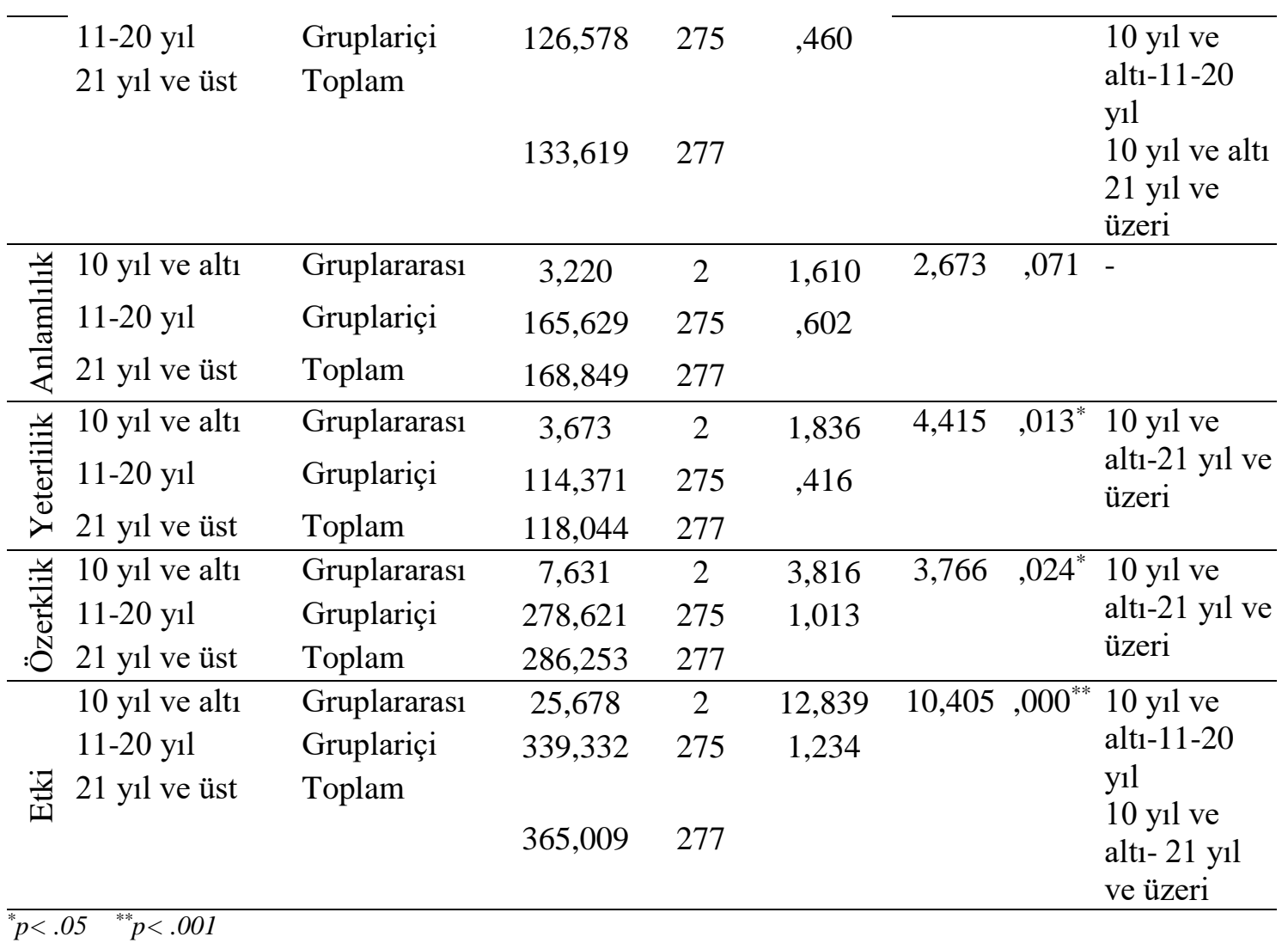

Tablo 4'ten de izlenebileceği gibi öğretim elemanlarının örgütsel özdeşleşmeye ilişkin alg1 düzeylerinde hizmet süresi değişkenine göre istatistiksel olarak anlamlı bir fark gözlenmemişken $\left(F_{(2-275)}=1,330, p>.05\right)$, psikolojik güçlendirmeyi algılama düzeylerinde hizmet süresi değişkenine göre istatistiksel olarak anlamlı bir fark bulunmuştur $\left(F_{(2-275)}=7,648\right.$, $p<.001)$. Yapılan LSD testi sonuçlarına göre 10 yıl ve altı hizmet süresine sahip öğretim elemanları $(\bar{X}=3,65)$ ile 11-20 y1l hizmet süresine sahip ögretim elemanları $(\bar{X}=3,92)$ ve 10 yıl ve altı hizmet süresine sahip öğretim elemanları $(\bar{X}=3,65)$ ile 21 yıl ve üzeri hizmet süresine sahip öğretim elemanları $(\bar{X}=4,11)$ arasında anlamlı bir farklılık olduğu saptanmıştır. Buna göre, 10 yıl ve altı hizmet süresine sahip öğretim elemanlarının psikolojik güçlendirmeyi algılama düzeylerinin diğer meslektaşlarından görece daha düşük olduğu belirlenmiştir. Öğretim elemanlarının, psikolojik güçlendirme düzeylerinin, hizmet süresi değişkenine göre yeterlilik $\left(F_{(2-}\right.$ $275)=4,415, p<.05)$, özerklik $\left(F_{(2-275)}=3,766, p<.05\right)$ ve etki $\left(F_{(2-275)}=10,405, p<.001\right)$ boyutlarda anlamlı bir farklılık gösterdiği, anlamlılık boyutuna $\left(F_{(2-275)}=2,673, p>.05\right)$ ilişkin tutumlarının ise farklılaşmadığı görülmüştür. LSD testi sonuçları ise yeterlilik boyutunda 10 yı1 ve altı hizmet süresine sahip öğretim elemanları $(\bar{X}=4,30)$ ile 21 yıl ve üzeri hizmet süresine sahip ögretim elemanları $(\bar{X}=4,68)$ arasında, özerklik boyutunda da 10 yıl ve altı hizmet süresine sahip öğretim elemanları $(\bar{X}=3,51)$ ile 21 yıl ve üzeri hizmet süresine sahip öğretim elemanları $(\bar{X}=3,98)$ arasında, etki boyutunda ise 10 yıl ve altı hizmet süresine sahip öğretim elemanları $(\bar{X}=2,52)$ ile 11-20 yıl hizmet süresine sahip ögretim elemanları $(\bar{X}=3,21)$ ve 10 yıl ve altı hizmet süresine sahip öğretim elemanları $(\bar{X}=2,52)$ ile 21 yıl ve üzeri hizmet süresine sahip öğretim elemanları $(\bar{X}=3,15)$ arasında anlamlı bir fark olduğunu göstermiştir.

Psikolojik güçlendirmenin dört alt boyutunun, örgütsel özdeşleşmeyi yordama gücünü saptamak amacıyla yapılan çoklu regresyon analizi sonuçları Tablo 5'de sunulmuştur. 
Tablo 5

Örgütsel Özdeşleşmenin Yordanmasına İlişkin Çoklu Regresyon Analizi Sonuçları

\begin{tabular}{lccccccc}
\hline Değişken & $\mathrm{B}$ & $\begin{array}{c}\text { Standart } \\
\text { Hata B }\end{array}$ & $\beta$ & $t$ & $p$ & İkili r & $\begin{array}{c}\text { K1smi } \\
\mathrm{r}\end{array}$ \\
\hline Sabit & 1,501 &, 299 & & 5,017 &, 000 & - & - \\
Anlamlıl1k &, 201 &, 074 &, 182 & 2,697 &, 007 &, 354 &, 161 \\
Yeterlilik &,- 184 &, 084 &,- 139 & $-2,180$ &, 030 &, 178 &,- 131 \\
Özerklik &, 332 &, 057 &, 391 & 5,844 &, 000 &, 530 &, 333 \\
Etki &, 135 &, 046 &, 180 & 2,928 &, 004 &, 437 &, 175 \\
\hline $\mathrm{R}=0.57$ & $\mathrm{R}^{2}=0.33$ & $\mathrm{~F}_{(4-273)}=32,996$ & $p=.000$ & & \\
\hline
\end{tabular}

Tablo 5'ten de görüldüğü gibi her dört değişkenin birlikte öğretim elemanlarının örgütsel özdeşleşme algıları ile orta düzeyde ve anlamı bir ilişki gösterdiği saptanmıştır $\left(\mathrm{R}=.57 ; \mathrm{R}^{2}=.33\right.$; $p<.01)$. Diğer yandan her dört değişkenin örgütsel özdeşleşmedeki varyansın \%33'ünü açıkladığ 1 belirlenmiştir. Standardize edilmiş regresyon katsayısına göre $(\beta)$ yordayıcı değişkenlerin öğretim elemanlarının örgütsel özdeşleşme düzeyleri üzerindeki göreli önem sırası "özerklik", "anlamlılık", "etki" ve "yeterlilik"tir. Regresyon katsayılarının anlamlılı̆̆ına ilişkin $t$-testi sonuçları incelendiğinde tüm boyutların, öğretim elemanlarının örgütsel özdeşleşme algılarının anlamlı birer yordayıcısı olduğu belirlenmiştir $(p<.05)$.

\section{Tartışma ve Sonuç}

Öğretim elemanlarının örgütsel özdeşleşme algıları ile psikolojik güçlendirme algıları arasındaki ilişkinin araştırıldığı bu çalışmada öncelikle öğretim elemanlarının bu iki değişkene ilişkin görüşleri incelenmiştir. Bulgular öğretim elemanlarının örgütsel özdeşleşme algılarının orta düzeyde olduğunu göstermiştir. Bu durum öğretim elemanlarının kendilerini çalıştıkları kuruma kısmen de olsa ait hissettikleri ancak görev yaptıkları okulları ile istenilen düzeyde özdeşleşemedikleri şeklinde yorumlanabilir. Eğitim örgütlerini daha iyi bir noktaya taşıyabilmek amacıyla çalışanların kendilerini kurumlarıyla özdeşleştirmeleri ve böylece örgütün başarısı için çaba sarf etmeleri önemli görülmektedir. Bu konuda yürütülen benzer bir çalışmada da öğretim elemanlarının örgütsel özdeşleşme algılarının orta düzeyde bulunduğu gözlenmiştir (Knippenberg ve Sleebos, 2006). Benzer bir bulguya Yıldız'ın (2013) ilkokul öğretmenleriyle yaptığı çalışmasında da ulaştığı görülmektedir. Ancak literatürde farklı meslek gruplarında çalışan katılımcıların örgütsel özdeşleşmeye yönelik algılarının yüksek düzeyde çıktığı bazı çalışmalar da bulunmaktadır (Ertürk, 2010; Mael ve Ashforth, 1992; Özdemir, 2010; Prati ve Zani, 2013). Derin ve Tuna (2017) ise İnönü Üniversitesi'nde görev yapan öğretim elemanlarının iletişim doyumunun örgütsel özdeşleşmeye etkisini inceledikleri çalışmalarında, katılımcıların örgütsel özdeşleşme düzeylerinin yüksek düzeyde olduğunu tespit etmişlerdir.

Araştırmada örgütsel özdeşleşme algısının öğretim elemanlarının cinsiyet, unvan ve hizmet süresi değişkenlerine göre farklılık göstermediği bulgusuna ulaşılmıştır. Buna göre erkek ve kadın öğretim elemanlarının örgütle bir olma, kendini örgüte ait hissetme, örgüttün kimliğini benimseme algıları benzer seviyede tespit edilmiştir. Nitekim Çakınberk ve diğerleri (2011), Özdemir (2010), Kurtulmuş ve Karabıyık (2016), Sezgin-Nartgün ve Demirer'in (2016) öğretmenlerle, Akın ve Saruhan'ın (2016) işletme çalışanlarıyla yürüttükleri araştırmalarında da katılımcıların örgütsel özdeşleşme algılarında cinsiyet değişkenine göre anlamlı bir farklılık bulunmamıştır. Ancak Derin ve Tuna (2017) çalışmalarında akademik personelin örgütsel özdeşleşme düzeyinin cinsiyet değişkenine göre erkeklerin lehine anlamlı bir farklılık gösterdiği sonucuna ulaşmışlardır. Aynı çalışmada ayrıca katılımcıların mesleki kıdem ve unvan değişkenine göre örgütsel özdeşleşme algılarının farklılaştığını rapor etmişlerdir. Erdoğdu ve Aydındă̆ (2013) ile Sezgin-Nartgün ve Demirer (2016) tarafından öğretmenlerle yürütülen araştırmalarda ise, kıdemi daha fazla olan çalışanların kıdemi daha az olan meslektaşlarından görece daha fazla örgütsel özdeşleşme algısına sahip oldukları tespit edilmiştir. Bulgular arasındaki farklılıklar, araştırmaların yürütüldüğü çalışma gruplarının farklı örgüt kültürlerinden 
etkileniyor olmasından kaynaklanıyor olabilir. Nitekim çeşitli araştırmalarda örgüt kültürünün örgütsel özdeşleşmeyi etkilediğine dair elde edilen sonuçlar da bu görüşü desteklemektedir (Özgözgü, 2016; Schrod, 2002).

Öğretim elemanlarının psikolojik güçlendirmeye yönelik algıları yüksek düzeyde olduğu belirlenmiştir. Literatürde bu bulguyla paralellik gösteren çalışmalar yer almaktadır (Altınkurt, Anasız ve Ekinci; 2016; Aslantaş, 2008; O’Brien, 2010; Polatcı ve Özçalık, 2013; Prati ve Zani, 2013; Tolay, Sürgevil ve Topoyan, 2012). Bu bulgudan hareketle, öğretim elemanlarının yaptıkları işi anlamlı bulduğu ve bu iş için kendilerini yeterli hissettikleri, örgütün işleyişine yönelik kararlarda önemli bir role sahip olduklarını düşündükleri söylenebilir. Ayrıca kalıtımcıların çalıştıkları örgütlerde kaynaklara ve bilgiye erişim imkânının kısıtlanmadığı, etkili bir geri bildirim mekanizmasının işletildiği, görev ve rol belirsizliğinin yaşanmadığı, katılımcilığın ve örgütün her bir üyesinin görüşlerinin önemsendiği ve bu sayede kendilerini güçlendirilmiş hissettikleri yorumu yapılabilir. Bu durumun, öğretim elemanlarının motivasyon ve performanslarını olumlu yönde etkileyerek, katılımcıların örgütle olan özdeşleşme düzeylerini de olumlu yönde etkileyeceği düşünülebilir. Psikolojik güçlendirmenin alt boyutlarının ortalamaları incelendiğinde, öğretim elemanlarının algıları yeterlilik alt boyutunda diğer boyutlara kıyasla daha yüksek iken etki boyutunda en düşük ortalamaya sahiptir. Bu bulguya göre öğretim elemanları en fazla yaptıkları iş için gerekli olabilecek bilgi ve beceriye sahip olduklarını hissetmekte ve kendilerine güvenmekte iken karar alma mekanizmalarında söz hakkına görece daha az sahip olduklarını ve bölümlerinde gerçekleşen olayların sonuçları üzerinde daha az etkiye sahip olduklarını düşünmektedirler yorumu yapılabilir. Bu bulgu Aslantaş (2008) ve Kesen'in (2015) işletme sektöründe, Joo ve Shim'in (2010) kamu çalışanlarıyla, Tolay ve diğerlerinin (2012) akademik personelle yapmış oldukları çalışmaların bulgularıyla benzerlik gösterirken, literatürde anlamlılık boyutunun ortalamasının diğer boyutlara göre daha yüksek çıktığ araştırmalara da rastlanmıştır (Meydan ve diğerleri, 2010; Polat ve diğerleri, 2010). Bunun sebebi diğer araştırmalardaki çalışma gruplarının farklılığı olabileceği gibi katılımcıların çalıştığı örgüt amaçlarının, örgüt kültürünün ve ikliminin de farklı olması olabilir.

Öğretim elemanlarının cinsiyet değişkenine göre psikolojik güçlendirmeye ilişkin alg1 düzeyleri incelendiğinde, ölçeğin genelinde ve yeterlilik boyutu hariç tüm alt boyutlarda erkeklerin lehine anlamlı bir fark çıkmıştır. Buna göre erkek katılımcılar işlerini daha anlamlı, önemli ve değerli bulurken, erkek öğretim üyeleri kadınlardan görece daha fazla karar verme fırsatına ve inisiyatif kullanabilme serbestliğine sahip olduklarını, örgütlerinde etkili olduklarını, fikirlerinin ciddiye alındığını hissettiklerini düşünmektedirler. Spreitzer ve diğerleri (1997) bu durumun sebebini kadınların sembolik statüleri nedeniyle örgütte kendilerini daha az güçlendirilmiş hissetmeleri ile açıklamıştır. Araştırmanın bulgusu ile benzer şekilde Speer, Peterson, Armstead ve Allen (2013) yaptıkları çalışmada ölçeğin tümünde erkek öğretim elemanlarının psikolojik güçlendirme algılarının kadın öğretim elamanlarının algılarına göre daha yüksek olduğu sonucuna ulaşmışlardır. Altınkurt ve diğerlerinin (2016) öğretmenlerle yürüttükleri çalışmada ise kadın öğretmenlerin psikolojik güçlendirme puanları erkek öğretmenlerden daha yüksek tespit edilmiştir. Literatürde ayrıca psikolojik güçlendirme algısının cinsiyet göre anlamlı bir farklılık göstermediği çalışmalara da rastlanılmıştır (Altındiş ve Özutku, 2011; Durmaz, 2011, Yarmac1, 2012). Unvan değişkenine göre katılımcı öğretim elemanlarının psikolojik güçlendirme algıları ölçeğin genelinde ve tüm alt boyutlarda anlamlı bir farklılık göstermiştir. Araştırma görevlilerinin psikolojik güçlendirme algılarının yardımcı doçent, doçent ve profesörlerden görece daha düşük olduğu belirlenmiştir. Bu durum akademik kariyer basamaklarında daha yüksek bir konuma sahip olan öğretim üyelerinin bilgi ve donanım açısından kendilerini daha yeterli hissetmeleri sebebiyle kendilerine daha fazla güvenmeleri sonucunda, sorumluluk bilinçlerinin artması ve inisiyatif alabilmeleri sayesinde psikolojik güçlendirme algılarının olumlu yönde etkilenmesi ile açıklanabilir. Katılımcıların hizmet süresi değişkenine göre psikolojik güçlendirmenin anlamlılık hariç tüm alt boyutlarına ilişkin görüşlerinin anlamlı bir şekilde farklılaştığı gözlenmiştir. Öğretim elemanlarının hizmet süresi arttıkça psikolojik güçlendirme algılarına ait ortalamaları artış göstermiştir. Bu bulgu hizmet süresi attıkça artan bilgi ve deneyime paralel olarak çalışanların sorumluluk almaya istekli olması ve kendi kararlarını 
rahatça uygulayabilmeleri ile açıklanabilir. Yarmacı'nın (2012) turizm, Koberg, Boss, Senjem ve Goodman'ın (1999) sağl1k sektöründe yürüttüğü araştırmalarında bu bulguya paralel olarak çalışma süresi arttıkça çalışan işgörenlerdeki güçlendirme algısının arttığını tespit etmiştir.

Öğretim elemanlarının örgütsel özdeşleşme ile psikolojik güçlendirme algıları arasında orta düzeyde, pozitif yönlü, anlamlı bir ilişki olduğu bulgusuna ulaşılmıştır. Daha açık bir ifade ile öğretim elemanlarının psikolojik güçlendirme algıları arttıkça örgütsel özdeşleşme düzeyleri de artmaktadır. Bu bulgu Akın ve Saruhan'ın (2016) küçük işletme personelleri, Erbay ve Turgut'un (2015) farklı meslek grubu çalışanları, Temel'in (2016) kamu çalışanları, Yarmacı'nın (2012) turizm sektörü çalışanları, Zhu ve diğerlerinin (2012) işletme çalışanlarıyla yürüttükleri araştırmaları destekler niteliktedir. Çalışmada ulaşılan diğer bir bulguya göre, psikolojik güçlendirmenin dört alt boyutunun tümünün, öğretim elemanlarının örgütsel özdeşleşme eğilimlerindeki değişkenliğin \%33'ünü açıkladığı, psikolojik güçlendirmenin, örgütsel özdeşleşmenin anlamlı bir yordayıcısı olduğu saptanmıştır. Buna göre öğretim elemanlarının psikolojik güçlendirme algılarının, örgütsel özdeşleşme düzeylerinin kestirilmesinde önemli ve istatistiksel olarak anlamlı bir rolünün olduğu anlaşılmaktadır. İşine yüklediği anlam ve değer ile kendini daha özerk ve yetkin hisseden öğretim elemanları örgütleriyle özdeşleşmekte ve böylece örgütün başarısını kendi başarısı, başarısızlığını ise kendi başarısızlığı olarak görmektedirler. Araştırma bulgusuna paralel olarak Bulut (2015) katılım bankası personelleriyle yürüttüğü çalışmasında psikolojik güçlendirmenin dört alt boyutunun örgütsel özdeşleşmedeki varyansın \%28'ini açıkladığını tespit etmiştir.

Genel olarak değerlendirdiğimizde araştırmanın sonucunda katılımcıların psikolojik güçlendirme algılarının yüksek, örgütsel özdeşleşme düzeylerinin ise orta düzeyde olduğu belirlenmiştir. Çalışmada ayrıca, katılımcıların psikolojik güçlendirme algıları ile örgütsel özdeşleşme düzeyleri arasında orta düzeyde bir ilişki tespit edilirken, psikolojik güçlendirmenin örgütsel özdeşleşmenin anlamlı bir yordayıcısı olduğu sonucuna ulaşılmıştır. Öğretim elemanlarının örgütsel özdeşleşme seviyelerinin yükseltilmesinin çalışanların performansının üzerinde olumlu etkileri olacağından, çalışanların örgüt değerleriyle bütünleşmesine imkân sağlayacak her türlü iletişim kanalının açık ve net olması, örgütün imajının artırılması, çalışanlara desteğin artırılması ve onlara değerli olduklarının hissettirilmesi gibi konularda kurum yöneticilerine önemli roller düşmektedir.Araştırma bulgularına göre, araştırma görevlilerinin psikolojik güçlendirme algılarının en düşük düzeyde olduğu düşünüldüğünde, araştırma görevlilerinin psikolojik güçlendirme algılarının daha az düzeyde tespit edilmesinin sebepleri daha ayrıntılı bir şekilde incelenebilir. Çeşitli aracı değişkenlerin psikolojik güçlendirme ve örgütsel özdeşleşme arasındaki ilişkiye etkisi de eklenerek daha kapsamlı çalışmalar yapılabileceği gibi her iki değişkenin diğer örgütsel davranış konularıyla ilişkisi de incelenebilir.Psikolojik güçlendirmenin özerklik alt boyutunun örgütsel özdeşleşme üzerinde en fazla etkiye sahip alt boyut olması, öğretim elemanlarının akademik özgürlük konusundaki hassasiyetine dikkat çekmektedir. Bu bağlamda öğretim elemanlarının herhangi bir baskı görmeden öğretme özgürlüğüne sahip olmasının yanında bilimsel çalışma konularını seçme, uygulama ve duyurma özgürlügüne de sahip olmaları onların örgütleri ile özdeşleşmelerinde etkili olabilir.

\section{Kaynaklar}

Akın, A. ve Saruhan, S. (2016). Küçük ölçekli işletmelerde psikolojik güçlendirme ile örgütsel özdeşleşme arasındaki ilişkinin tespiti üzerine bir araştırma, AÇÜ Uluslararası Sosyal Bilimler Dergisi, 2(2), 25-42.

Altındiş, S. ve Özutku, H. (2011). Psikolojik güçlendirme ve güçlendirmeyi etkileyen faktörler: Türkiye'deki devlet hastanelerinde bir araştırma. Afyon Kocatepe University Journal of Social Sciences, 13(1), 161-191.

Altınkurt, Y., Anasız, B. T. ve Ekinci, C. E. (2016). Öğretmenlerin yapısal ve psikolojik güçlendirilmeleri ile örgütsel vatandaşlık davranışları arasındaki ilişki. Eğitim ve Bilim, 41(187), 79-96. 
Aslantaş, C. C. (2008). Yöneticiye duyulan güvenin ve psikolojik güçlendirmenin örgütsel vatandaşl1k davranışı üzerindeki etkilerini belirlemeye yönelik görgül bir çalışma. TiSK Akademi, 3(5), 100-117.

Ashforth, B. E. ve Mael, F. (1989). Social identity theory and the organization. Academy of Management Review, 14(1), 20-39.

Ashforth, B. E., Harrison, S. H. ve Corley, K. G. (2008). Identification in organizations: An examination of four fundamental questions. Journal of Management, 34(3), 325-374. doi:10.1177/0149206308316059

Avey, J. B., Hughes , L. W., Norman, S. M. ve Luthans, K. W. (2008). Using positivity, transformational leadership and empowerment to combat employee negativity. Leadership\&Organization Development Journal, 29(2), 110-126. doi:10.1108/01437730810852470

Balc1, A., Baltac1, A., Fidan, T., Cereci, C. ve Acar, U. (2012). Örgütsel sosyalleşmenin, örgütsel özdeşleşme ve örgütsel vatandaşl1kla ilişkisi: İlköğretim okulu yöneticileri üzerinde bir araştırma. Ë̆itim Bilimleri Araştırmaları Dergisi, 2(2), 47-74.

Bartels, J. (2006). Organizational identification and communication: Employees' evaluation of internal communication and its effects on identification at different organizational levels (Unpublished doctoral thesis). University of Twente, Netherlands.

Bowen, D. E. ve Lawler, E. E. (1992). The empowerment of service workers: What, why, how, and when. Sloan Management Review, 33, 31-39.

Brown, M. E. (1969). Identification and some conditions of organizational involvement. Administrative Science Quarterly, 14(3), 346-355. doi: 10.2307/2391129

Bulut, E. (2015). Personel güçlendirme, örgütsel özdeşleşme ve çalışan performansı arasındaki ilişki: Katılım bankalarında araştırma (Yayımlanmamış yüksek lisans tezi). Beykent Üniversitesi Sosyal Bilimler Enstitüsü, İstanbul.

Byrne, B. M. ve Campbell T. L. (1999). Cross-cultural comparisons and the presumption of equivalent measurement and theoretical structure: A look beneath the surface. Journal of Cross Cultural Psychology,30, 555-574. doi:10.1177/0022022199030005001

Carless, A. S. (2004). Does psychological empowerment mediate the relationship between psychological climate and job satisfaction? Journal of Business and Psychology, 18(4), 405-425. doi: 10.1023/B:JOBU.0000028444.77080.c5

Cheney, G. ve Tompkins, P. K. (1987). Coming to terms with organizational identification and commitment. Communication Studies, 38(1), 1-15. doi:10.1080/10510978709368225

Christ, O., Dick, R., Wagner, U. ve Stellmacher, J. (2003). When teachers go the extra mile: Foci of organisational identification as determinants of different forms of organisational citizenship behaviour among school teachers. British Journal of EducationalPsychology, 73(3), 329-341. doi: 10.1348/000709903322275867

Conger, J. A. ve Kanungo, R. N. (1988). The empowerment process: Integrating theory and practice. The Academy of Management Review, 13(3), 471-482.

Çakınberk, A., Derin, N. ve Demirel, E. T. (2011). Örgütsel özdeşleşmenin örgütsel bağl1lıkla biçimlenmesi: Malatya ve Tunceli özel eğitim kurumları örneği. Işsletme Araştırmaları Dergisi,3(1), 89-121.

Çetinkaya, M. ve Çimenci, S. (2014). Örgütsel adalet algısının örgütsel vatandaşlık davranışı üzerindeki etkisi ve örgütsel özdeşleşmenin aracılık rolü: Yapısal eşitlik modeli çalışması. Yönetim Bilimleri Dergisi, 12(23), 237-278.

Deci, E. L., Connel, J. P. ve Ryan. R. M. (1989). Self-determination in a work organization. Journal of Applied Psychology, 74(4), 580-590. doi:10.1037/0021-9010.74.4.580

Derin, N. ve Tuna, H. (2017). Akademik bir örgütte iletişim doyumunun örgütsel özdeşleşmeye etkisi. Journal of Selcuk Communication, 9(4), 119-128.

Durmaz, I. (2011). Psikolojik güçlendirme algısının iç girişimcilik üzerine etkisi (Yayımlanmamış doktora tezi). Gazi Üniversitesi Sosyal Bilimleri Enstitüsü, Ankara.

Dutton, J. E., Dukerich, J. M. ve Harquail, C. V. (1994). Organizational images and member identification. Administrative Science Quarterly, 39(2), 239-263. doi:10.2307/2393235 
Edwards, M. R. (2005). Organizational identification: A conceptual and operational review. International journal of management reviews, 7(4), 207-230. doi:10.1111/j.14682370.2005.00114.x

Erbay, E. ve Turgut, T. (2015). Yapısal güçlendirme ve örgütle özdeşleşme arasındaki ilişkide psikolojik güçlenmenin ara değişken etkisi. İktisadi ve İdari Bilimler Dergisi, 37(2), 261-284.

Erdoğdu, M. Y. ve Aydındağ, Z. (2013). Öğretmenlerin kurumsal özdeşleşme ve bağl1lıklarının algılanan yönetici davranışları acısından incelenmesi. İstanbul Sabahattin Zaim Üniversitesi Sosyal Bilimler Enstitüsü Dergisi, 1(2), 158-153.

Ergeneli, A. ve Arı, G. S. (2005). Krizde işten çıkarmaların banka yöneticileri üzerine etkileri: Örgütsel bağl1lık, güven ve güçlendirme algıları. Ankara Üniversitesi Siyasal Bilgiler Fakültesi Dergisi, 60(1), 121-148.

Erstad, M. (1997). Empowerment and organizational change. International Journal of Contemporary Hospitality Management, 9(7), 325-333. doi:10.1108/ 09596119710190976

Ertürk, A. (2010). Exploring predictors of organizational identification: Moderating role of trust on the associations between empowerment, organizational support, and identification. European Journal of Work and Organizational Psychology, 19(4), 409-441. doi:10.1080/13594320902834149

Foote, N. N. (1951). Identification as the basis for a theory of motivation. American sociological review, 16(1), 14-21.

Gabler, C. B., Rapp, A. ve Richey, R. G. (2014). The effect of environmental orientation on sales person effort and participation: The moderating role of organizational identification. Journal of Personal Selling \& Sales Management, 34(3), 173-187. doi:10.1080/08853134.2014.890906

George, D. ve Mallery, P. (2001). SPSS for windows step by step: a simple guide and reference. Needham Heights: AllynBacon.

Gist, M. E. (1987). Self-Efficacy: Implications for organizational behavior and human resource management. The Academy of Management Review, 12(3), 472-485.

Hekman, D. R., Steensma, H. K., Bigley, G. A. ve Hereford, J. F. (2009). Effects of organizational and professional identification on the relationship between administrators' social influence and professional employees' adoption of new work behavior. Journal of Applied Psychology, 94(5), 1325-1335. doi: 10.1037/a0015315

İşcan, Ö. F. (2006). Dönüştürücü/etkileşimci liderlik algısı ve örgütsel özdeşleşme ilişkisinde bireysel farklılıkların rolü. Akdeniz İ.I.B.F. Dergisi, 11, 160-177.

Joo, B. K. Ve Shim, J. H. (2010). Psychological empowerment and organizational commitment: the moderating effect of organizational learning culture, Human Resource Development International, 13(4), 425-441, doi: 10.1080/13678868.2010.501963

Karasar, N. (2014). Bilimsel araştırma yöntemi. Ankara: Nobel

Kesen, M. (2015). Psikolojik güçlendirme çalışanların sosyal kaytarma davranışlarını azaltır mı? Journal of Yaşar University, 10(38), 6531-6540.

Kline, R. B. (2005). Principles and practice of structural equations modeling. New York: Guilford Press.

Koberg, C. S., Boss, R. W., Senjem, J. C. ve Goodman, E. A. (1999). Antecedents and outcomes of empowerment: Empirical evidence from the healthcare industry. Group\&Organization Management, 24(1), 71-90. doi:10.1177/1059601199241005

Koçel, T. (2010). İşletme Yöneticiliği. İstanbul: Beta.

Kurtulmuş, M. ve Karabıyık, H. (2016). Farkl1lıkların yönetiminin öğretmenlerin örgütsel özdeşleşmesine ve işten ayrilma niyetine etkisi. International Journal of Human Sciences, 13(1), 1324-1341. doi:10.14687/ijhs.v13i1.3597

Lee, A. N. ve Nie, Y. (2014). Understanding teacher empowerment: Teachers' perceptions of principal's and immediate supervisor's empowering behaviours, psychological 
empowerment and work-related outcomes. Teaching and Teacher Education, 41, 6779. doi:10.1016/j.tate.2014.03.006

Lee, M. ve Koh, J. (2001). Is empowerment really a new concept? The International Journal of Human Resource Management, 12(4), 684-695. doi: 10.1080/713769649

Lee, S. M. (1971). An empirical analysis of organizational identification. Academy of Management Journal, 14(2), 213-226.

Leech, N. L., Barrett, K. C. ve Morgan, G. A. (2011). SPSS for intermediate statistics: Use and interpretation (4th ed.). New York, NY: Routledge/Taylor \& Francis.

Mael, F. ve Ashforth, B. E. (1992). Alumni and their alma mater: A partial test of there formulated model of organizational identification. Journal of Organizational Behavior, 13(2), 103123. doi: $10.1002 /$ job. 4030130202

Menon, S. T. Ve Hartmann, L. C. (2002). Generalizability of Menon's empowerment scale: Replication and extension with Australian data. International Journal of Cross Cultural Management, 2, 137-153. doi:10.1177/1470595802002002860

Meydan, C. H., Polat, M. ve Burmaoğlu, S. (2010). Bireyin güçlendirilmişlik algısının örgütle özdeşleşmesine etkisi: Kamuda bir araştırma. KHO Bilim Dergisi, 20(1), 37-60.

O’Brien, J. L. (2010). Structural empowerment, psychological empowerment and burnout in registered staff nurses working in outpatient dialysis centers (Unpublished doctoral thesis). The State University of New Jersey, Newark, New Jersey.

Özdemir, A. (2010). Örgütsel özdeşleşmenin algılanan örgütsel destek, cinsiyet ve k1dem değişkenlerine göre incelenmesi. Türkiye Sosyal Araştırmalar Dergisi, 14(1), 237-250.

Özgözgü, S. (2016). Kurumsal imaj, örgüt kültürü ve örgütsel özdeşleşme ilişkisi. Kastamonu Eğitim Dergisi, 25(2), 581-596.

Polat, M. ve Meydan, C. H. (2010). Örgütsel özdeşleşmenin sinizm ve işten ayrılma niyeti ile ilişkisi üzerine bir araştırma. KHO Bilim Dergisi, 9, 145-172.

Polat, M., Meydan, C. H. ve Tokmak, İ. (2010). Personel güçlendirme, örgütsel özdeşleşme ve örgütsel sinizm ilişkisi üzerine bir araştırma. KHO Bilim Dergisi, 20(2), 1-22.

Polatcı, S. ve Özçalık, F. (2013). Yapısal ve psikolojik güçlendirmenin işyeri nezaketsizliği ve tükenmişliğe etkisi. İşletme Bilimi Dergisi, 1(1), 17-34.

Prati, G. ve Zani, B. (2013).The relationship between psychological empowerment and organizational identification. Journal of Community Psychology, 41(7), 851-866.

Quinn, R. E. ve Spreitzer, G. M. (1997). The road to empowerment: Seven questions every leader should consider. Organizational Dynamics, 26(2), 37-49. doi:10.1016/S00902616(97)90004-8

Reade, C. (2001). Antecedents of organizational identification in multinational corporations: Fostering psychological attachment to the local subsidiary and the global organization. International Journal of Human Resource Management, 12(8), 1269-1291. doi:10.1080/09585190110083794

Riketta, M. (2005). Organizational identification: A meta-analysis. Journal of Vocational Behavior, 66, 358-384. doi:10.1016/j.jvb.2004.05.005

Schrodt, P. (2002). The relationship between organizational identification and organizational culture: Employee perceptions of culture and identification in a retail sales organization. Communication Studies, 53(2), 189-202. doi: 10.1080/10510970209388584

Scott, C. R., Corman, S. R. ve Cheney, G. (1998). Development of a structurational model of identification in theorganization. CommunicationTheory, 8(3), 298-336. doi:10.1111/j.1468-2885.1998.tb00223.x

Scott, S.G., ve Lane, V.R. (2000). A stakeholder approach to organizational identity. Academy of Management Review, 25(1), 43-62. doi:10.2307/259262

Sezgin-Nartgün, Ş. ve Demirer, S. (2016). Öğretmenlerin örgütsel sosyalleşme ve özdeşleşme düzeylerinin birlikte çalışma yeterliklerine etkisi. Mersin Üniversitesi Ĕgitim Fakültesi Dergisi, 12(1), 474-503. doi: 10.17860/efd.21683 
Sluss, D. M., Klimchak, M. ve Holmes, J.J. (2008). Perceived organizational support as a mediator between relational Exchange and organizational identification. Journal of Vocational Behavior, 73(3), 457-464. doi:10.1016/j.jvb.2008.09.001

Somuncuoğlu, A. B. (2013). Psikolojik güçlendirme ve iş tatmini arasındaki ilişki ve bir uygulama (Yayınlanmamış yüksek lisans tezi). İstanbul Üniversitesi Sosyal Bilimler Enstitüsü, İstanbul.

Speer, P. W., Peterson, N. A., Armstead, T. L. ve Allen, C. T. (2013). The influence of participation, gender and organizational sense of community on psychological empowerment: The moderating effects of income. American Journal of Community Psychology,51(1-2), 103-113. doi:10.1007/s10464-012-9547-1

Spreitzer, G. M. (1995). Psychological empowerment in the workplace: Dimensions, measurement, and validation. The Academy of Management Journal, 38(5), 1442-1465. doi: $10.2307 / 256865$

Spreitzer, G. M., Kizilos, M. A. ve Nason, S. W. (1997). A dimensional analysis of the relationship between psychological empowerment, and effectiveness, satisfaction, and strain. Journal of Management, 23, 670-704. doi:10.1177/014920639702300504.

Stander, M. W. ve Rothmann, S. (2010). Psychological empowerment, job insecurity and employee engagement. SA Journal of Industrial Psychology, 36(1), 1-8. doi:10.4102/sajip.v36i1.849

Stoner, J. ve Gallagher, V. C. (2011). The glass is half full: The positive effects of organizational identification for employees higher in negative affectivity. Journal of Applied Social Psychology, 41(7), 1793-1817. doi:10.1111/j.1559-1816.2011.00773.x

Sürgevil, O., Tolay, E. ve Topoyan, M. (2013). Yapısal güçlendirme ve psikolojik güçlendirme ölçeklerinin geçerlilik ve güvenilirlik analizleri. Journal of YasarUniversity, 8(31), 5371-5391.

Tak, B. ve Çiftçioğlu, A. (2009). Algılanan örgütsel prestij ile örgütsel bağl1lık ve örgütsel özdeşleşme arasındaki ilişkilerin incelenmesine yönelik bir araştırma. Akdeniz İ.I.B.F. Dergisi, 18,100-116.

Taştan, S. (2012). Bir pozitif psikoloji kavramı olarak örgütle özdeşleşmenin psikolojik güçlendirme algısı ve gönüllü performans davranışı arasındaki ilişkide ara değişken rolünün değerlendirilmesi: Gıda sektöründe yapılan bir araştırma. Organizasyon ve Yönetim Bilimleri Dergisi, 4(1), 227-238.

Temel, E. (2016). Dönüşümcü liderlik ve psikolojik güçlendirme arasındaki ilişkide örgütsel özdeşleşmenin aracılık rolü: Nazilli'deki kamu kurumlarında bir uygulama (Yayımlanmamış yüksek lisans tezi). Adnan Menderes Üniversitesi Sosyal Bilimler Enstitüsü, Aydın.

Thomas, K. W. ve Velthouse, B. A. (1990). Cognitive elements of empowerment: An "Interpretive" model of intrinsic task motivation. Academy of Management Review, 15(4), 666-681. doi:10.5465/AMR.1990.4310926

Tokgöz, E. ve Seymen, O. A. (2013). Örgütsel güven, örgütsel özdeşleşme ve örgütsel vatandaşl1k davranışı arasındaki ilişki: bir devlet hastanesinde araştırma. Öneri Dergisi, 10(39), 6176.

Tolay, E., Sürgevil, O. ve Topoyan, M. (2012). Akademik çalışma ortamında yapısal ve psikolojik güçlendirmenin duygusal bağl1lık ve iş doyumu üzerindeki etkileri. Ege Akademik Bakış, 12(4), 449-465.

Tompkins, P. K. ve Cheney, G. (1985). Communication and unobtrusive control in contemporary organizations. Organizational communication: Traditional themes and new directions, 13, 179-210. doi:10.4135/9781446261279

Turunç, Ö. ve Çelik, M. (2010). Algılanan örgütsel desteğin çalışanların iş-aile, aile-iş çatışması, örgütsel özdeşleşme ve işten ayrılma niyetine etkisi: Savunma sektöründe bir araştırma. Atatürk Üniversitesi Sosyal Bilimler Enstitüsü Dergisi, 14(1), 209-232. 
Tüzün, İ. K. (2006). Örgütsel güven, örgütsel kimlik ve örgütsel özdeşleşme ilişkisi; Uygulamalı bir çalışma (Yayımlanmamış doktora tezi). Gazi Üniversitesi Sosyal Bilimler Enstitüsü, Ankara.

Vacharakiat, M. (2008).The relationships of empowerment, and organizational commitment between Filipino and American registered nurses working in the USA (Unpublished master thesis). George Mason Üniversitesi, Fairfax, VA.

Van Dick, R., Van Knippenberg, D., Kerschreiter, R., Hertel, G. ve Wieseke, J. (2008). Interactive effects of work group and organizational identification on job satisfaction and extra-role behavior. Journal of Vocational Behavior, 72, 388-399. doi:10.1016/j.jvb.2007.11.009

Van Knippenberg, D. ve Sleebos, E. (2006). Organizational identification versus organizational commitment: Self-definition, social exchange, and job attitudes. Journal of Organizational Behavior, 27(5), 585-605. doi: 10.1002/job.378

Walsh, K. ve Gordon, J. R. (2008). Creating an individual work identity. Human Resource Management Review, 18(1), 46-61. doi:10.1016/j.hrmr.2007.09.001

Walumbwa, F. O., Mayer, D. M., Wang, P., Wang, H., Workman, K. ve Christensen, A. L. (2010). Linking ethical leadership to employee performance: The roles of leader-member exchange, self-efficacy, and organizational identification. Organizational Behavior and Human Decision Processes, 115(2), 204-213. doi:10.1016/j.obhdp.2010.11.002

Yarmac1, N. (2012). Psikolojik güçlendirmenin örgütsel özdeşleşmeye etkisi: Otel işletmelerinde bir araştırma (Yayımlanmamış yüksek lisans tezi). Afyon Kocatepe Üniversitesi Sosyal Bilimler Enstitüsü, Afyon.

Yıldız, K. (2013). Öğretmenlerin örgütsel özdeşleşmeleri ile örgütsel iletişimleri arasındaki ilişkinin incelenmesi. Kuram ve Uygulamada Eğitim Bilimleri, 13(1), 251-272.

Yürür, S. ve Demir, K. (2011). Örgütsel adalet ve psikolojik güçlendirme: Karş1lıklı etkileri üzerine bir araştırma. Süleyman Demirel Üniversitesi İktisadi ve İdari Bilimler Fakültesi Dergisi, 16(3), 311-335.

Zhu, W., Sosik, J. J., Riggio, R. E. ve Yang, B. (2012). Relationships between transformational and active transactional leadership and followers' organizational identification: The role of psychological empowerment. Journal of Behavioral and Applied Management, 13(3), 186-212.

\section{Extended Abstract \\ Introduction}

Nowadays, organizations expect their employees to work consistently in their workplaces for a long time, to act with a feeling of loyalty, and even identify their individual identities with their organizations (Çakınberk, Derin \& Demirel, 2011). Organizational identification is defined as an individual having a sense of belonging to a certain organization and defining himself as a member of that organization (Mael \& Ashforth, 1992). Identified employees support organization with solidarity feelings (Riketta, 2005), and they become more motivated toward difficult tasks by making organizational goals their own goals (Edwards, 2005). When literature is examined, it is seen that organizational identification is related to many different concepts such as organizational support, organizational prestige, organizational commitment, organizational justice, leadership, cynicism, intention to leave work, organizational trust, organizational socialization, job satisfaction (Balc1, Baltac1, Fidan, Cereci \& Acar, 2012; Bose \& Patnaik, 2015; Çakınberk et al., 2011; Çetinkaya \& Çimenci, 2014; İşcan, 2006; Polat \& Meydan, 2010; Sluss, Klimchak \& Holmes, 2008; Tak \& Çiftçioğlu, 2009; Turunç \& Çelik, 2010; Tüzün, 2006; Walumbwa et al, 2010; Van Dick, Van Knippenberg, Kerschreiter, Hertel \& Wieseke, 2008). One of these concepts emerges as psychological empowerment. According to Thomas and Velthouse (1990), psychological empowerment is synonymous with motivation, to increase the lower-level employees' power to do work, strengthening their self-esteem and independence feelings, and feeling themselves psychologically secure. If this definition is conceived, it can be interpreted that individuals with high perceptions of psychological empowerment also tend to have high level organizational identification. As a matter of fact, some researchers reported that psychological 
empowerment is the determinant of organizational identification in their studies (Ak1n \& Saruhan, 2016; Bulut, 2015; Ertürk, 2010; Polat, Meydan \& Tokmak, 2010; Taştan, 2012; Zhu, Sosik, Riggio \& Yang, 2012). From this point of view, in this study, it was aimed to investigate the relationship between psychological empowerment and organizational identification according to the perceptions of academic staff. In this context, the following questions were asked in the research:

1. What is the level of academic staff's psychological empowerment and organizational identification perceptions?

2. To what extent are academic staff's perceptions about psychological empowerment and organizational identification related?

3. How do academic staff's perceptions about psychological empowerment and organizational identification vary according to their gender, title and tenure?

4. To what extent do academic staff's perceptions about psychological empowerment explain the variability of organizational identification?

\section{Method}

The study, designed as a correlational research, has a total of 278 academic staff participants (119 females and 159 males) working in state universities located in Turkey. The data were collected during the spring semester of 2013-2014 academic year. Organizational identification of participants was measured by using the 7-item and single-dimensional "Organizational Identification Scale (OIS)" developed by Mael and Ashforth (1992) and adapted to Turkish by Tüzün (2006). To investigate the psychological empowerment perceptions of the participants, the "Psychological Empowerment Scale (PES)" developed by Spreitzer (1995) and adapted into Turkish by Sürgevil, Tolay and Topoyan (2013) was used. The scale consists of 12-item and 4 sub dimensions (meaning, competence, self-determination and impact). Both of the scales are Likert type scale that ranges from "(1) totally disagree" to "(5) totally agree". The Cronbach alpha coefficients are respectively .87 and .90 within the current study. The construct validity of the scales used within the study was tested by confirmatory factor analysis. The data set was primarily examined for linearity, homogeneity, and variances. Afterwards, the data were analyzed by conducting $t$ test, ANOVA, Pearson correlation and multiple linear regression.

\section{Findings}

Results showed that organizational identification level of participants is at moderate level and did not differ regarding their gender, working experience in academia and title. Psychological empowerment perception level of participants is at high level and the competence sub-dimension has the highest level whereas impact sub-dimension has the lowest level. Psychological empowerment perception level of male participants is higher than female participants. Research assistants" psychological empowerment perception level is lower than assistant professors, associate professors and professors. As the working experience in academia increased, psychological empowerment perception level of participants also increased. The findings also indicated that, as the psychological empowerment perception level of participants increased, their organizational identification level increased. According to the other findings of the study it was revealed that all of the four sub-dimensions of psychological empowerment explained $33 \%$ of the variance in the organizational identification, and psychological empowerment is a significant predictor of organizational identification.

\section{Conclusion and Discussion}

As a result of the research, it was determined that participants have high levels of psychological empowerment and medium levels of organizational identification. It was found that there is a moderate, positive, meaningful relationship between organizational identification and psychological empowerment perceptions of the academic staff. More explicitly, as the perceptions of psychological empowerment of the academic staff increase, the levels of organizational identification also increase. The researches supporting this finding are found in the 
Öğretim Elemanlarının Algılarına göre Psikolojik Güçlendirme ile Örgütsel Özdeşleşme Arasındaki

İlişkinin İncelenmesi

literature (Akın \& Saruhan, 2016; Erbay \& Turgut, 2015; Temel, 2016; Yarmac1, 2012; Zhu et al., 2012). It was also found that the perceptions of the academic staff about all four dimensions of psychological empowerment account for $33 \%$ of the variability in organizational identification levels and psychological empowerment is a significant predictor of organizational identification. According to this, the academic staff who feel themselves more autonomous and competent with the meaning and value they put into their work are identified with their organizations and thus see the success of the organization as their own success and its failure as their own failure. 